Keywords:

- Early-Holocene glacier chronology

- Schmidt-hammer exposure-age dating

- Glacier sensitivity to climatic variability

- ${ }^{10}$ Be surface exposure dating

- Radiocarbon dating

- Preboreal Erdalen Event

- Equilibrium-line altitude

Received:

14. May 2020

Accepted:

8. July 2020

Published online:

31. August 2020

\section{Early-Holocene moraine chronology, Sogne- fjell area, southern Norway: evidence for multiple glacial and climatic fluctuations within the Erdalen Event ( 10.2-9.7 ka)}

\author{
Richard A. Shakesby ${ }^{1}$, John A. Matthews ${ }^{1}$, Stefan Winkler ${ }^{2}$, Derek Fabel ${ }^{3}$ \&
} P. Quentin Dresser ${ }^{1}$

${ }^{1}$ Department of Geography, College of Science, Swansea University, Singleton Park, Swansea SA2 8PP, UK ${ }^{2}$ Department of Geography and Geology, Julius-Maximilians University Würzburg, Am Hubland, 97074 Würzburg, Germany

${ }^{3}$ SUERC AMS Laboratory, Rankine Avenue, Scottish Enterprise Technology Park, East Kilbride G75 OQF, UK

E-mail corresponding author (Richard Shakesby): r.a.shakesby@swansea.ac.uk

In southern Norway, early-Holocene climatically induced glacier expansion episodes have been recognised at $\sim 11.1,10.5,10.2,9.7$ and $8.2 \mathrm{ka}$, but the only convincingly dated, single- or doubleridged moraines are those associated with the regional Erdalen Event (i.e., $10.2-9.7 \mathrm{ka}$ ). We applied three numerical-age dating techniques to sequences of up to five moraine ridges deposited by the former Sognefjell ice cap and by Styggedalsbreen, a large cirque glacier in the nearby Hurrungane massif. On inner and outer ridges and relict patterned ground proximal to the moraines, six ${ }^{10} \mathrm{Be}$ and eight Schmidt hammer (SHD) surface exposure ages were obtained. Thirteen radiocarbon dates were obtained from stream-bank mire sediments proximal to the Sognefjell moraines. The basal date is similar to those from cores in an adjacent lake indicating disappearance of the Sognefjell ice-cap immediately following the Erdalen Event. Three of four SHD results, and one of three ${ }^{10} \mathrm{Be}$ surface exposure ages from the Sognefjell moraines support this. At Styggedalsbreen, two of three ${ }^{10} \mathrm{Be}$ surface exposure ages lie between the $8.2 \mathrm{ka}$ (Finse) and Erdalen Event, though $1 \sigma$ dating uncertainties only overlap with the former: the third is clearly affected by cosmogenic nuclide inheritance. SHD results also suggest the younger event, but this is attributed to lithological differences between the Schmidt-hammer calibration site and the sampled moraine boulders. Considering the chronological evidence as a whole, supported by equilibrium-line altitude (ELA) calculations for Styggedalsbreen, we conclude that the moraines were formed by up to five short but distinct fluctuations of these ice masses during the Erdalen Event. This indicates more complex decadal- to centennial-scale glacier variations and climatic perturbations within the Erdalen Event than previously recognised. The implied exceptional glaciological sensitivity to climate variability is attributed to local topographic factors causing glacial fluctuations in response to relatively small ELA changes.

Shakesby, R.A., Matthews, J.A., Winkler, S., Fabel, D. \& Dresser, P.Q. 2020: Early-Holocene moraine chronology, Sognefjell area, southern Norway: evidence for multiple glacial and climatic fluctuations within the Erdalen Event ( 10.2-9.7 ka). Norwegian Journal of Geology 100, 202014. https://dx.doi.org/10.17850/njg100-3-2.
(C) Copyright the authors. This work is licensed under a Creative Commons Attribution 4.0 International License. 


\section{Introduction}

Until comparatively recently, dating of Holocene moraines in southern Norway has been mainly limited to Little Ice Age (LIA) sequences, which were formed in this most pronounced late-Holocene expansion episode (e.g., Andersen \& Sollid, 1971; Matthews, 1991; Bickerton \& Matthews, 1993; Winkler et al., 2003; Matthews, 2005). Relative-age dating to distinguish the late-Holocene from far less common earlier Holocene moraines has been based on large differences in lichen size and degree of boulder weathering (e.g., Matthews \& Shakesby, 1984; McCarroll, 1994; Matthews, 2005). Radiocarbon dating of early-Holocene moraines has been restricted to minimum ages from basal peat inside moraine limits, often supported by pollen analysis (e.g., Vorren, 1973; Nesje, 1984; Mottershead \& Collin, 1976; Shakesby et al., 1990; Dahl et al., 2002; Nesje, 2009). Unlike moraine stratigraphic and dendrochronological studies in the European Alps (Patzelt \& Bortenschlager, 1973; Patzelt, 1974; Röthlisberger, 1986; Nicolussi \& Patzelt, 2000; Holzhauser et al., 2005; Jerin et al., 2006), finds of organic material overridden by moraines have been scarce in southern Norway and no dates of this type have so far proved to be from early- or mid-Holocene times because of different conditions (but see Dahl \& Nesje, 1992). During the last 30 years, dating of early-Holocene glacier expansion episodes in southern Norway has been significantly improved by radiocarbon dating of organic material associated with distal glaciolacustrine and stream-bank mire sediments, which have provided near-continuous, uninterrupted records of glacier size variations (e.g., Nesje \& Kvamme, 1991; Nesje et al., 1991, 2000, 2001; Karlén \& Matthews, 1992; Matthews \& Karlén, 1992; Dahl \& Nesje, 1994, 1996; Seierstad et al., 2002; Dahl et al., 2003; Lie et al., 2004; Bakke et al., 2005a, 2005b, 2013; Shakesby et al., 2007; Matthews \& Dresser, 2008; Aa \& Sønstegaard, 2019).

Distal sediments, however, do not record glacier extent, which is normally only achieved by direct dating of the corresponding moraines. To achieve such direct dating, two exposure-age dating techniques are available for independent numerical-age dating of early-Holocene moraines: Schmidthammer exposure-age dating (SHD) (Shakesby et al., 2006, 2011; Matthews \& Owen, 2010; Matthews \& Winkler, 2011; Matthews \& McEwen, 2013; Tomkins et al., 2016, 2018a) and surface exposure dating using in situ produced terrestrial cosmogenic nuclides (Gosse \& Phillips, 2001; Balco et al., 2008; Balco, 2011; Dunai, 2010). In southern Norway, whilst SHD has been refined and applied to a number of early-Holocene moraines (Shakesby et al., 2006; Matthews \& Owen, 2010; Matthews \& Winkler, 2011; Matthews et al., 2014), surface exposure dating has so far been limited to moraines deposited by an outlet glacier of the Jostedalsbreen ice cap (Matthews et al., 2008) and by a cirque glacier in western Jotunheimen (Shakesby et al., 2008).

We present new dating evidence and discuss the implications for arguably the best preserved earlyHolocene moraine sequences in southern Norway. These moraines record readvance or stillstand phases of an early-Holocene ice cap on the Sognefjell plateau and of Styggedalsbreen, a cirque glacier in the neighbouring Hurrungane massif (Fig. 1). We apply a multiproxy-dating approach involving three techniques (Schmidt-hammer and ${ }^{10} \mathrm{Be}$ surface exposure age dating, and radiocarbon dating), which reveals their strengths and weaknesses and allows exploration of their complementarity. The study leads, moreover, to new insights into the glacial chronology of southern Norway and the distinctive response of these ice masses to early-Holocene decadal- to centennial-scale climatic variations. 


\section{Background}

The Sognefjell plateau forms an undulating surface between the Jostedalsbreen ice cap and Jotunheimen mountains, ranging from $\sim 1200 \mathrm{~m}$ to $\sim 1400 \mathrm{~m}$ a.s.l., above which rise mountains reaching up to 2000 m a.s.l. (e.g., Gjesingefjellet, 1481 m; Krossh $\varnothing, 1627$ m; Fannaråknosi, 2068 m) and into which are cut narrow valleys such as Rydalen (Fig. 1). The Hurrungane massif is a radially dissected, dome-like mountain mass $\sim 10 \mathrm{~km}$ in diameter lying south of Sognefjell. Erosion by valley and cirque glaciers has here produced alpine topography with sharp peaks and connecting arêtes that rise above $2000 \mathrm{~m}$ and reach $2403 \mathrm{~m}$ at the centre of the massif at Store Skagastølstindane (Storen). Climatic data from the closest meteorological station (Sognefjellhytta, $1413 \mathrm{~m}$ a.s.l.) indicate a mean annual air temperature of $-3.1^{\circ} \mathrm{C}$ (July mean, $+13.4^{\circ} \mathrm{C}$; January mean $-10.7^{\circ} \mathrm{C}$ ) and a mean annual precipitation of $860 \mathrm{~mm}$ (Aune, 1993; Førland, 1993). The bedrock geology of the region consists largely of pyroxene-granulite gneiss (Lutro \& Tveten, 1996) but other lithologies, including various types of gabbro, peridotite intrusions and veins of quartz-feldspar are also present (Koestler, 1989; www.geo.ngu.no/kart/berggrunn). Fragments of the veins were used for ${ }^{10} \mathrm{Be}$ surface exposure dating.

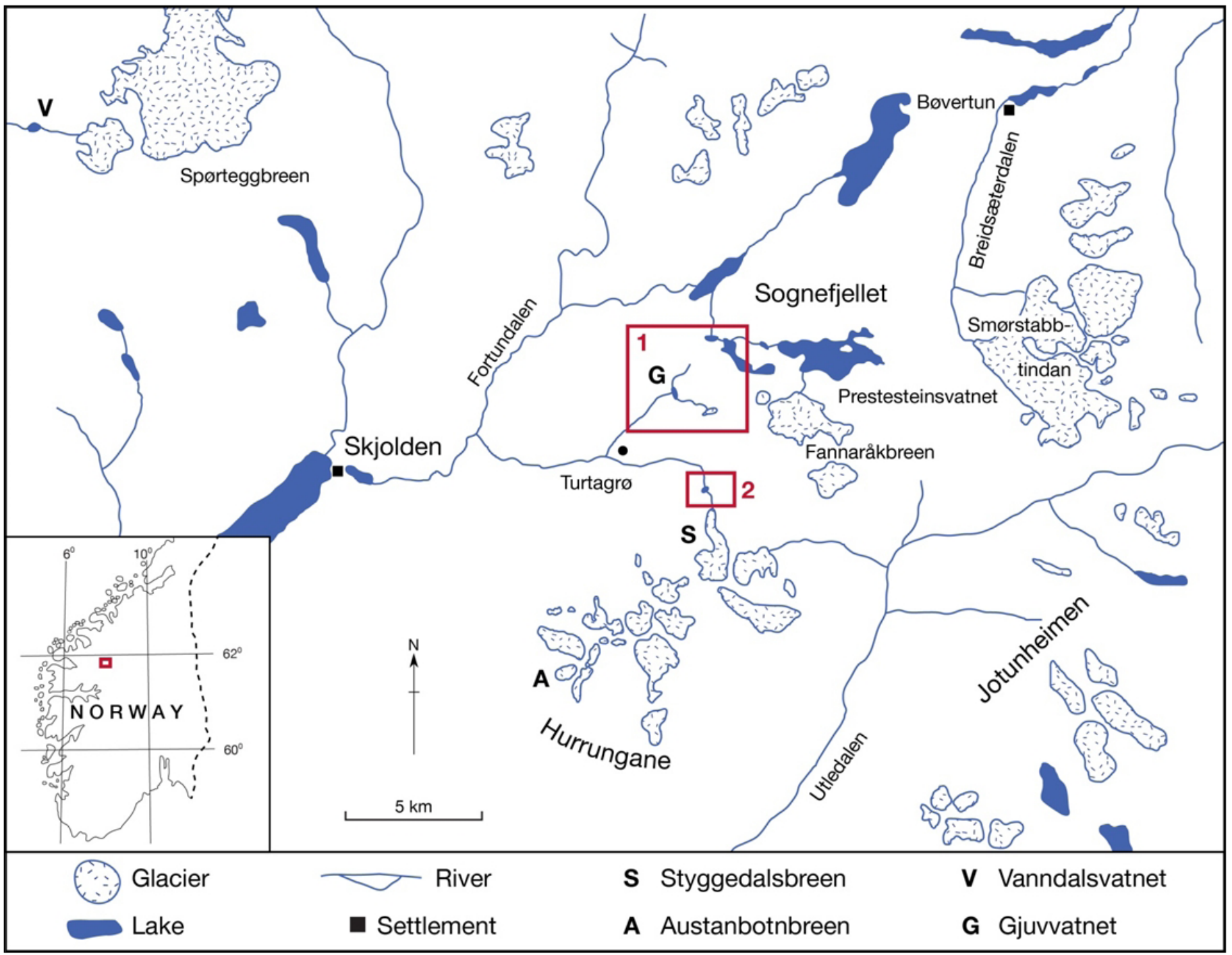

Figure 1. Location of the Sognefjell (box 1) and Styggedalsbreen (box 2) study areas in southern Norway. 
Mostly glacio-lacustrine evidence from southern Norway suggests that the retreat of disintegrating Younger Dryas ice was interrupted in the early Holocene by up to five comparatively short-lived, firmly dated centennial- to millennial-scale glacier expansion episodes: the Jondal I Event ( 11.1 ka), Jondal II Event ( 10.5 ka), early Erdalen Event ( 10.2 ka), late Erdalen Event ( 9.7 ka) and the Finse Event ( 8.2 ka) (Dahl \& Nesje, 1992; Matthews et al., 2000; Nesje \& Dahl, 2001; Nesje et al., 2001; Dahl et al., 2002; Bakke et al., 2005b; Matthews et al., 2005; Matthews \& Dresser, 2008; Nesje, 2009). Following the Finse Event, most if not all glaciers apparently disappeared at least once prior to $\sim 6 \mathrm{ka}$. Glaciers readvanced or reformed (neoglaciation) between $\sim 6 \mathrm{ka}$ and $\sim 4 \mathrm{ka}$, with most reaching their post-Erdalen Event maxima during the LIA (Matthews, 1991; Nesje et al., 2008). Early-Holocene moraines have so far only been clearly linked to the Erdalen Event, with moraines possibly representing Jondal Events inferred from relative-age dates and morphostratigraphy at the northern Folgefonna type site or from equilibrium-line altitude estimates (Bakke et al., 2005b; Lukas, 2007).

The Finse Event is the southern Norway equivalent of the Greenland '8.2 ka Event' (O'Brien et al., 1995; Alley et al., 1997; Rohling \& Pälike, 2005), which is widely regarded as the foremost northern Atlantic, centennial-scale, Holocene cooling event (e.g., Alley \& Ágústsdóttir, 2005; Rohling \& Pälike, 2005; Ellison et al., 2006), and consistently linked to a distinct, clearly dated, minerogenic layer in distal lake and stream-bank sediments in southern Norway (e.g., Nesje \& Dahl, 2001). Finding a Finse Event moraine has, however, proved elusive, which has led to the conclusion that the Finse Event glacier expansion episode was less extensive than that of the LIA. ${ }^{10} \mathrm{Be}$ and ${ }^{26} \mathrm{Al}$ surface exposure ages from an early-Holocene moraine at Austanbotnbreen in western Jotunheimen (Fig. 1) suggested a possible Finse Event origin (Shakesby et al., 2008), but later SHD evidence led Matthews \& Winkler (2011) to reject it and conclude that only small, very responsive glaciers might produce such moraines, given the brevity of this event. More recent research, however, has suggested that the Finse Event may have spanned as much as 1000 years from its gradual beginning to abrupt termination (Bakke et al., 2013) and had more impact than the late ( 9.7 ka) Erdalen Event (Paus et al., 2019).

The well preserved early-Holocene moraines selected for our study are located within: (1) a $20 \mathrm{~km}^{2}$ rectangle of western Sognefjell extending from the eastern shores of Prestesteinsvatnet in the northeast and the western slopes of Fannaråknosi in the southeast, to Gjesingefjellet in the northwest and Rydalen in the southwest (Figs. 1 \& 2); and (2) a smaller $\sim 2.8 \mathrm{~km}^{2}$ area encompassing the outer margins of the glacier foreland of Styggedalsbreen, a relatively large, north-facing cirque glacier occupying a hanging valley in the northern Hurrungane massif (Figs.1 \& 3).

In the Sognefjell study area, there is a distinct, sinuous belt of up to five subparallel moraine ridges up to $\sim 8 \mathrm{~m}$ high, which descends gradually southwestwards from $\sim 1550 \mathrm{~m}$ north of Steindalsnosi to $\sim 1380 \mathrm{~m}$ east of Gjuvvatnet (Fig. 2). Farther west, on steeper terrain, a single looping ridge at $\sim 1050 \mathrm{~m}$, crossing the floor of Rydalen north of Turtagrø, can be linked to the outer ridge of the belt. A moraine associated with a small glacier on the northern side of Steindalsnosi at $\sim 1550 \mathrm{~m}$ is interpreted, following Vorren (1973), as a composite Preboreal/LIA moraine, although lichen sizes indicate only the latter age. There has been no published research into Sognefjell plateau moraines since Vorren (1973) assigned them to the Preboreal. Early-Holocene glacial history has, however, been investigated elsewhere in the vicinity. In Gjuvvatnet (Fig. 2), lake sediment cores gave a basal radiocarbon date of 10246-9556 cal BP on detrital wood, which was considered a reliable date for ice withdrawal (Karlén \& Matthews, 1992; Matthews \& Karlén, 1992). Recoring confirmed deglaciation by $\sim 10 \mathrm{ka}$ (Nesje, 2009). No silt/clay band indicating the Finse Event was identified in Gjuvvatnet, but lake cores from Nedste Hervavatnet and Vanndalsvatnet, to the northeast and northwest respectively, indicated meltwater events of this age (Nesje et al., 2006; Hormes et al., 2009). In addition, at the former site, two sediment spikes dating from $\sim 8.5$ to $\sim 9.4$ ka were recorded, but no evidence of the Erdalen Event was detected. 


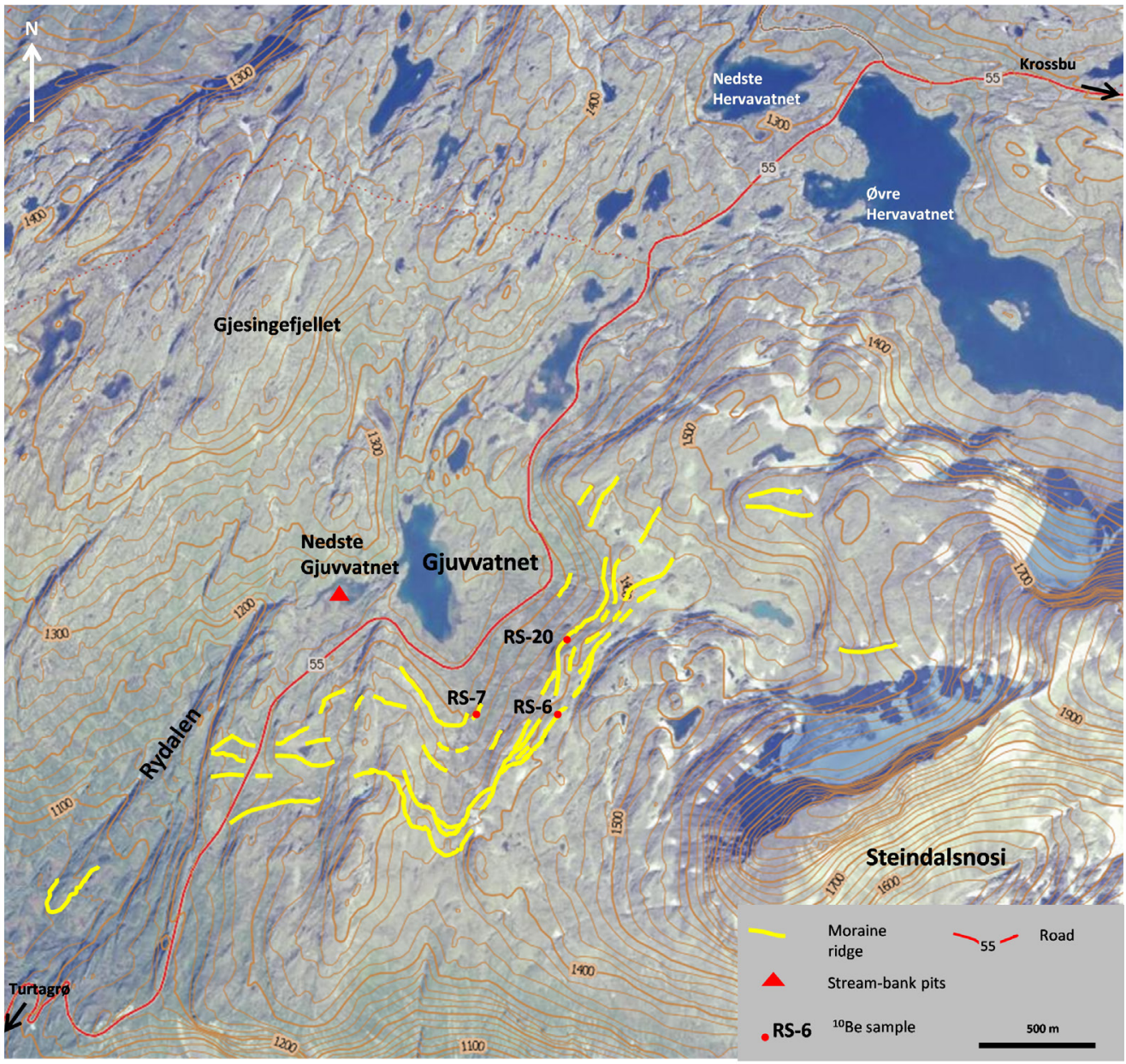

Figure 2. Sognefjell study area showing moraines, and locations of Rydalen stream-bank pits and boulders sampled for ${ }^{10}$ Be surface exposure dating. Contours at $20 \mathrm{~m}$ intervals. () The Norwegian Mapping Authority, Geovekst and municipalities, Jotunheimen 2004.

In the Styggedalsbreen study area, on raised ground at the outer margin of the glacier foreland lies a concentric arc of at least five subparallel moraine ridges 2-6 $\mathrm{m}$ high (Fig. 3). They can be linked to a further isolated series of three parallel ridges up to $\sim 1480 \mathrm{~m}$ a.s.l. on the northern slope of the neighbouring valley of Styggedalen (Ahlmann, 1922, 1940; Vorren, 1973; Bickerton \& Matthews, 1993; Matthews, 2005; Fig. 3). Together, these early-Holocene moraines indicate formation by a combined ice mass occupying Styggedalen and the Styggedalsbreen valley. The oldest of four radiocarbon dates from soil beneath the outer LIA moraine gave an age of 2741-3287 cal BP (Griffey \& Matthews, 1978), but the dates were subsequently attributed to soil mean residence time rather than to moraine age (Matthews, 1985). Otherwise, there have been no published numerical dates relating to early-Holocene glacier fluctuations at Styggedalsbreen. 


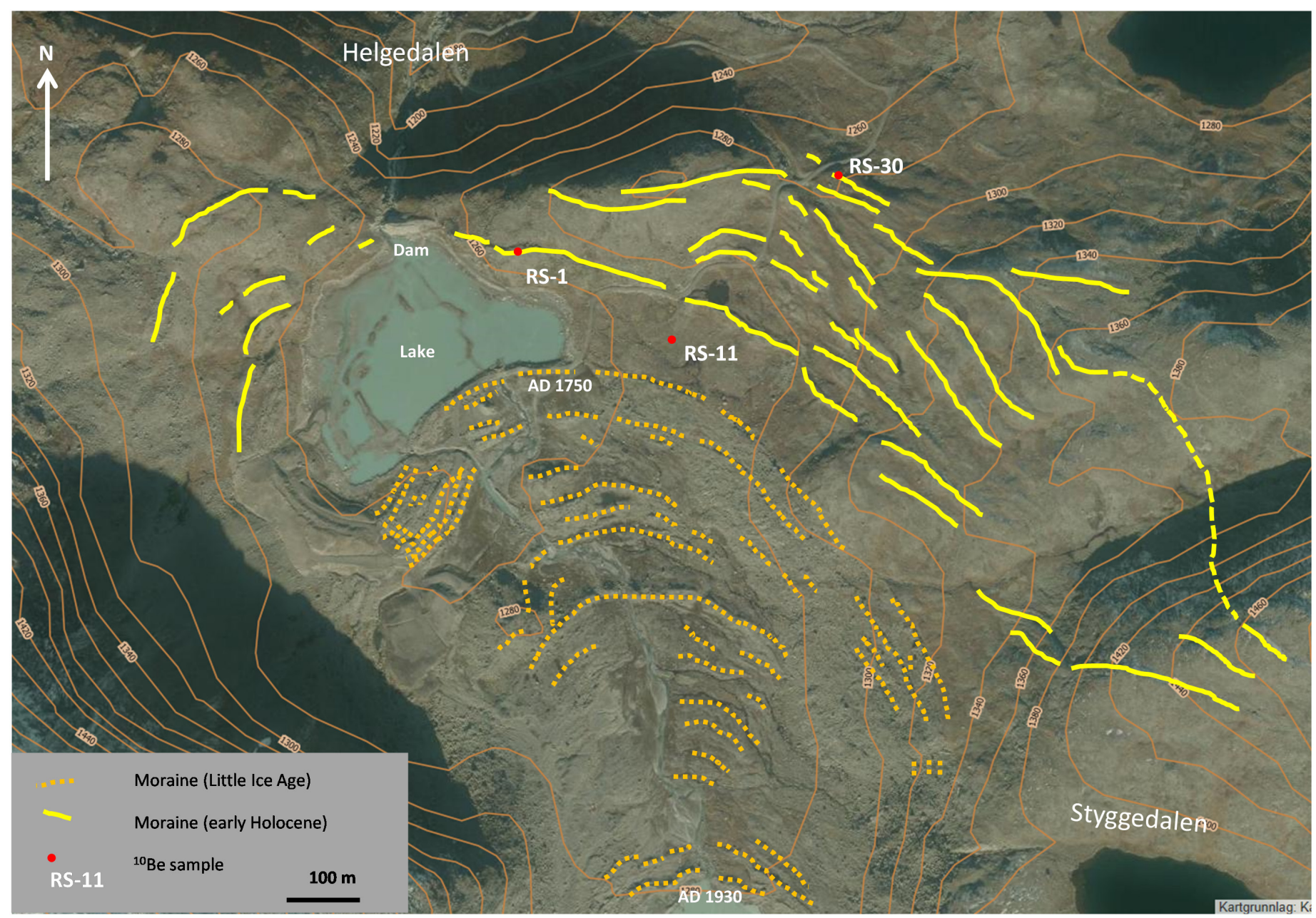

Figure 3. Styggedalsbreen study area showing moraines and locations of boulders sampled for ${ }^{10}$ Be surface exposure dating. Little Ice Age (LIA) and early-Holocene moraines are differentiated. The $A D 1750$ LIA outer and AD 1930 moraines are marked. Much of the area near the southwestern shore of the lake has been modified by hydro-electricity works with consequent destruction of moraines. Contours at $20 \mathrm{~m}$ intervals. (C) The Norwegian Mapping Authority, Geovekst and municipalities, Sogn 2010.

\section{Methods}

\section{Radiocarbon dating}

Stratigraphic description and sampling for radiocarbon dating were carried out from two open pits in a stream-bank mire associated with the outlet stream of Nedste Gjuvvatnet, proximal to the Sognefjell moraine belt (Rydalen 1 and 2; Fig. 4A, B). Thirteen dating samples $0.5-1.0 \mathrm{~cm}$ thick were collected from visible thin organic layers within the minerogenic sediment comprising moss, moss with detrital twigs and leaves together with $1 \mathrm{~cm}$-thick samples from the upper and/or lower boundaries of thicker peat layers. Samples were subsequently stored at $4^{\circ} \mathrm{C}$ prior to acid washing and dating in the former Swansea Radiocarbon Laboratory using conventional techniques. Dates were corrected for $\delta^{13} \mathrm{C}$ values and calibrated using the program of Stuiver \& Reimer (2017) and the IntCal13 datasets in Reimer et al. (2013). 

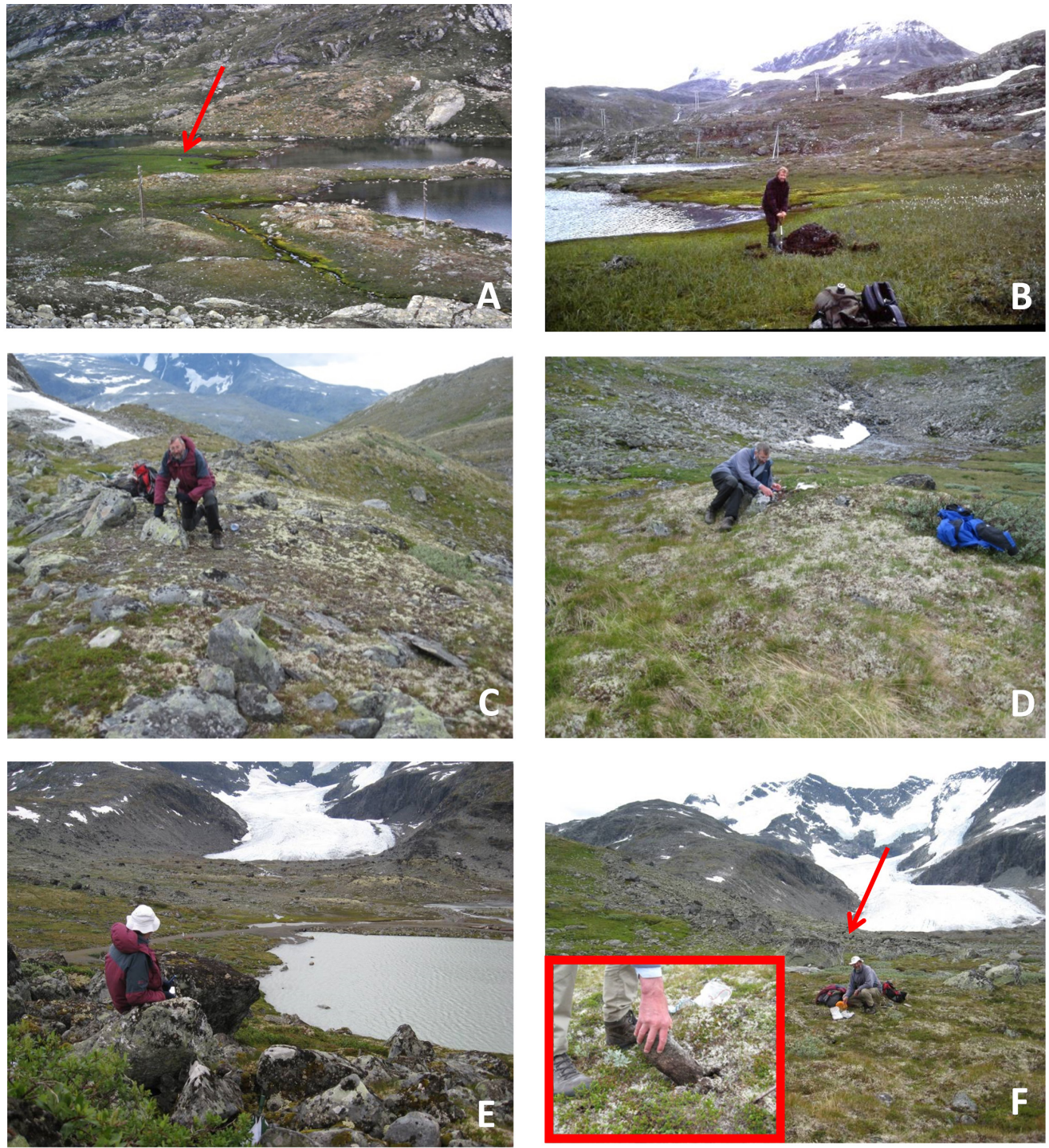

Figure 4. (A) Location of stream-bank mire (arrowed) beside Nedste Gjuvvatnet; (B) Close-up view of stream-bank mire pit (Rydalen1) (Steindalsnosi peak in the background); (C) site of RS-6 boulder (next to figure) sampled for ${ }^{10} \mathrm{Be}$ surface exposure dating on outer Sognefjell moraine ridge (Gjuvvatnet lies to the right); (D) site of RS-7 boulder sampled for ${ }^{10}$ Be surface exposure dating (in front of figure) on inner Sognefjell moraine ridge; (E) site of RS-1 boulder sampled for ${ }^{10}$ Be surface exposure dating (leant on by figure) viewed southwards across the artificially dammed lake, with Styggedalsbreen in the background. Note the relative flatness of the glacier foreland; (F) Site of RS-11 boulder sampled for ${ }^{10}$ Be surface exposure dating obtained from inactive patterned ground between the Preboreal inner and Little Ice Age outer (arrowed) moraines on Styggedalsbreen foreland. Inset image shows boulder partly removed from its embedded position in the ground.

\section{Schmidt-hammer exposure-age dating}

Schmidt-hammer R-values were recorded using a mechanical N-type hammer (Proceq, 2006), tested before and after use on a standard test anvil (cf., McCarroll, 1987, 1994). The best developed, near-crest sections (numbered 1 and 2 ) of the outer $(\mathrm{O})$ and inner (I) early-Holocene moraine ridges from Sognefjell and Styggedalsbreen were sampled. Within two contiguous subsections of each moraine section, mean R-values were calculated for five impacts on each of 75 boulders. The $95 \%$ confidence limits for each pair of subsections overlapped, so that for clarity only the section mean values (based on 150 boulders) are presented. Horizontal or near-horizontal surfaces were used where possible on virtually all boulders encountered. Boulders deemed too small or unstable were avoided, as were edges and cracks, 
lichen thalli and wet surfaces (e.g., Shakesby et al., 2006; Matthews \& Owen, 2010). Although unusual lithologies, especially quartzite and peridotite, were avoided, considerable heterogeneity within the pyroxene-granulite gneiss (cf., Koestler, 1989) could still have affected the mean R-values (see below).

SHD dating and age calibration follows procedures detailed in Matthews \& Owen (2010), Matthews \& Winkler (2011) and Matthews \& McEwen (2013). With no suitable pairs of reliably dated control points found in either study area, a modified approach compared to recent studies developed by Matthews \& Owen (2010) was adopted involving two calibration curves based on two control points of known age in neighbouring regions (S \& E Smørstabbtindan and W Smørstabbtindan; Fig. 1), from which the better predictor of moraine ages is assessed.

Use of two control points assumes that, first, R-values lie on a ratio scale, which is demonstrated by the near-linear relationship between R-values above $\sim 30$ and rock compressive strength (hardness), established under controlled conditions (Proceq, 2006). Mean R-values in this study ranged from 39.03 to $\mathbf{4 5 . 9 5}$ for moraine sections. The second assumption is that the temporal rate of decline in R-value with weathering during the Holocene is approximately linear. This was tested and validated for the Holocene time-scale by Shakesby et al. (2011). Over longer time-scales, weathering rates should approach a balance between removal of weathering products and continued rock surface breakdown such that weathering rates decline (Colman, 1981; Colman \& Dethier, 1986; see also Tomkins et al., 2018b). Linear rates over the Holocene can be attributed to relatively slow subaerial chemical weathering in periglacial environments (André, 1996; Nicholson, 2008, 2009; Matthews \& Owen, 2011). Clearly, any control point age errors will affect the derived calibration curve, so that accurately dated control surfaces are paramount

\section{${ }^{10} \mathrm{Be}$ surface exposure dating}

Rock samples for ${ }^{10} \mathrm{Be}$ surface exposure dating were obtained from boulders: (1) embedded in the crests of innermost and outermost ridges (RS-7 and RS-6) together with a large boulder from the crest of an intermediate ridge (RS-20) of the Sognefjell moraine belt (Figs. 3 \& 4C, D); and (2) from innermost and outermost moraine ridges (RS-1 and RS-30) and from a surface boulder on inactive patterned ground (RS-11) between the LIA outer limit and the innermost early-Holocene ridge on the Styggedalsbreen foreland (Figs. 3 \& 4E, F). The samples were processed in the School of Geographical and Earth Sciences at Glasgow University. Mineral separation was carried out on the $0.25-0.5 \mathrm{~mm}$ fraction, including etching with $\mathrm{HCl} / \mathrm{HNO}_{3}$, magnetic separation, floatation, and removal of residual feldspars with pyro-phosphoric acid. Quartz was purified by successive $\mathrm{HF} / \mathrm{HNO}_{3}$ leaching and purity assessed by flame AAS measurement of $\mathrm{Al}$.

Sample preparation for Be measurement was carried out at the Glasgow University - Scottish Universities Environmental Research Centre (GU - SUERC) Cosmogenic Isotope Laboratory following procedures outlined by Child et al. (2000). After adding ${ }^{9}$ Be carrier, quartz was dissolved in concentrated HF. Be was extracted from the solution using column chemistry. Precipitated $\mathrm{Be}(\mathrm{OH})_{2}$ was dried and oxidised to $\mathrm{BeO}$, and mixtures of $\mathrm{BeO}$ and $\mathrm{Nb}(1: 6)$ were pressed into cathodes. ${ }^{10} \mathrm{Be} /{ }^{9} \mathrm{Be}$ values in these AMS targets were measured at the SUERC AMS laboratory (Xu et al., 2010). Process blanks, prepared with the samples, were used to subtract blank/background levels of ${ }^{10} \mathrm{Be}$.

${ }^{10} \mathrm{Be}$ surface exposure ages were calculated using version 3 of the online exposure age calculator described by Balco et al. (2008) and subsequently updated (http://hess.ess.washington.edu/; wrapper: 3.0.2; get_age: 3.0 .2 ; muons: $1 \mathrm{~A}$, alpha $=1$; validate: validate_v3_input.m - 3.0; consts: 3.0.4). We used the most advanced scaling method (LSDn; Lifton et al., 2014) and the western Norway (Goehring et al., 2012) and CRONUS Primary Be-10 -2015 (Borchers et al., 2016) calibration datasets from the ICE-D 
database (http://calibration.ice-d.org/), excluding samples as per the original publications. Uncertainties in the calculated ages using the different scaling methods and calibration datasets are statistically indistinguishable. The results in the text are based on the western Norway calibration dataset (Goehring et al., 2012) as it is nearest to the study sites. Age uncertainties given in the text and accompanying table and diagram include the analytical and production rate uncertainties.

Exposure-age calculations are presented without adjustments for: (1) glacio-isostatic uplift; (2) atmospheric mass redistribution; (3) post-depositional erosion $(\varepsilon=0)$; and (4) the effects of shielding by sediment, vegetation and snow. The first two time-dependent effects are currently thought to offset each other, at least to an extent. Whilst glacio-isostastic uplift is relatively easily calculated, the other effect is not because equivalent, easily accessible, last-glacial-maximum-to-present-day models of atmospheric pressure redistribution do not exist (Balco, 2019). Post-depositional erosion of quartz-rich moraine boulders, like those sampled in this study, is likely to have been negligible (André, 2002; Owen et al., 2007). Even an improbably high rate of loss of $0.5 \mathrm{~mm} \mathrm{ka}^{-1}$ (which exceeds the maximum measured losses of $\sim 0.2 \mathrm{~mm} \mathrm{ka}^{-1}$ for quartzite) would cause the calculated ages to increase by $<1 \%$. The Sognefjell and Styggedalsbreen boulder moraines are thought to be stable so that any sediment cover on ridge crests from which the sampled boulders were collected is thought likely to have been thin and removed shortly after deposition. The sites lie above the treeline with little shrub development, so that it is unlikely that crest boulders would have been shielded by vegetation. Records from recent decades for both locations show that there is usually a dry snow cover (0-2\% liquid water content) that typically persists for six months (December-May) with depths on occasions and in places reaching 2-4 $\mathrm{m}$ (www. seNorge.no). The density of the dry snow at both locations is probably unlikely to exceed $0.2 \mathrm{~g} \mathrm{~cm}^{-3}$ (Shakesby et al., 2008) and, while a $4 \mathrm{~m}$-deep snow of this density would require an increase in age by $10.7 \%$, for boulders on moraine crests a far more realistic snow thickness of $0.5 \mathrm{~m}$ with the same density would increase the calculated ages by only $1.5 \%$.

\section{Results}

\section{Radiocarbon ages}

The stratigraphic interpretations and calibrated median radiocarbon dates and $2 \sigma$ age ranges obtained for the stream-bank mire pits are shown in Fig. 5, with radiocarbon and corresponding calibrated ages given in Table 1. (Only the $\pm 2 \sigma$ calibrated age ranges are given below.) Grey silt dominated beneath 22 and $44 \mathrm{~cm}$-thick surface peat layers (Fig. 5). In Rydalen 1, there was a peat layer at 60-66 cm depth and, in Rydalen 2, seven, thin $(0.5-1.0 \mathrm{~cm})$, moss layers between 64.5 and $107 \mathrm{~cm}$, and a further two with detrital twig and leaf litter at 181.5-182 cm and 189.5-190 cm. Dates from organic sediment above $106.5 \mathrm{~cm}$ depth in both pits are no older than $\sim 6 \mathrm{ka}$. Dates from the surface peat layer bases differ by $>2000$ years (677-553 cal BP and 3155-2880 cal BP in Rydalen 1 and 2, respectively). The two dates from below $180 \mathrm{~cm}$ depth in Rydalen 2 are 9534-9141 cal BP and 10,266-9905 cal BP for moss layers containing detrital organic matter (Table 1). The dates in Rydalen 2 are mostly in chronological order, with exceptions deviating by no more than a few hundred years between $\sim 4400$ and $\sim 6200$ cal BP. 

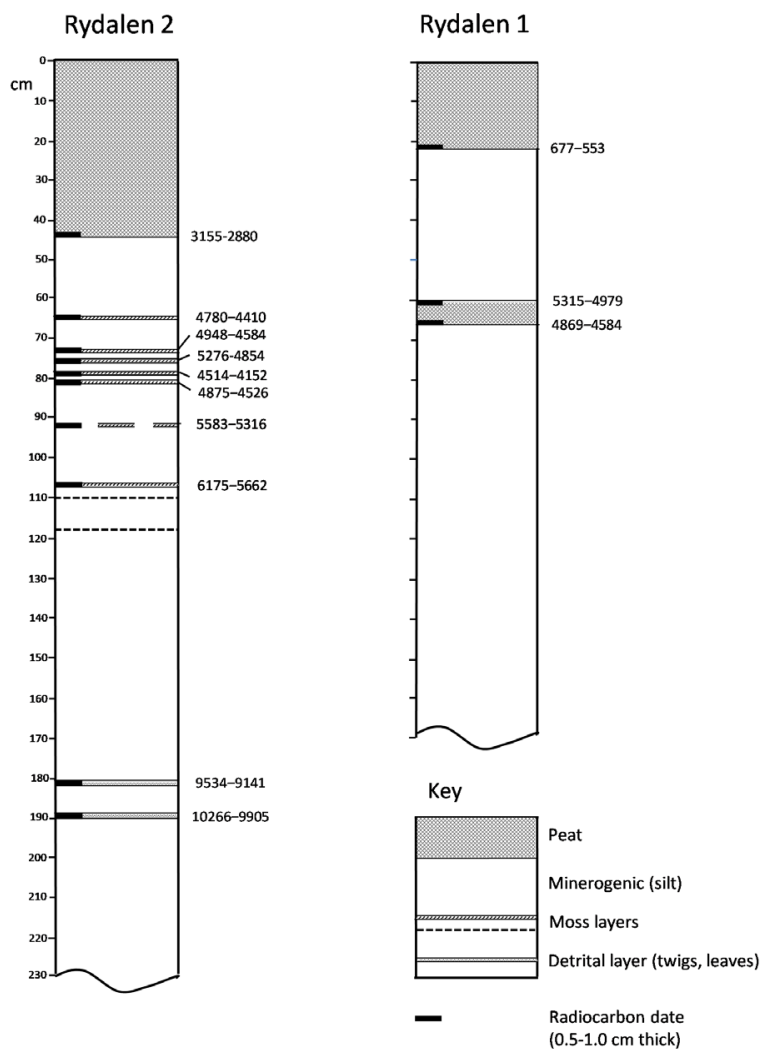

Figure 5. Stratigraphic interpretations and calibrated radiocarbon age ranges $( \pm 2 \sigma)$ for the two stream-bank mire pits.

Table 1. Radiocarbon dates and calibrated median age and calibrated age ranges ( $\pm 1 \sigma$ and $\pm 2 \sigma$ ) for organic samples from the stream-bank mire sites Rydalen 1 and Rydalen 2. Calibrations are based on the IntCal13 calibration curve (Reimer et al., 2013). See Fig. 5.

\begin{tabular}{|c|c|c|c|c|c|c|}
\hline Laboratory code & Depth (cm) & $\delta^{13} \mathrm{C}(\% \circ)$ & ${ }^{14} \mathrm{C}$ date & $\begin{array}{c}\text { Median age } \\
\text { (cal BP) }\end{array}$ & $\begin{array}{c}\text { Age range } \\
\text { (cal BP) }( \pm 1 \sigma)\end{array}$ & $\begin{array}{c}\text { Age range } \\
\text { (cal BP) }( \pm 2 \sigma)\end{array}$ \\
\hline \multicolumn{7}{|l|}{ Rydalen 1} \\
\hline SWAN-1009 & $21-22$ & -24.6 & $660 \pm 40$ & 615 & $667-563$ & $677-553$ \\
\hline SWAN-1010 & $60-61$ & -24.5 & $4520 \pm 50$ & 5163 & $5300-5057$ & 5315-4979 \\
\hline SWAN-1011 & $65-66$ & -26.4 & $4230 \pm 50$ & 4747 & $4854-4653$ & $4869-4584$ \\
\hline \multicolumn{7}{|l|}{ Rydalen 2} \\
\hline SWAN-1012 & $43-44$ & -23.0 & $2880 \pm 40$ & 3009 & $3070-2950$ & $3155-2880$ \\
\hline SWAN-1013 & $64.5-65.0$ & -21.0 & $4010 \pm 40$ & 4482 & $4520-4428$ & $4780-4410$ \\
\hline SWAN-1014 & $72.5-73.0$ & -21.8 & $4240 \pm 50$ & 4760 & $4859-4656$ & $4948-4584$ \\
\hline SWAN-1015 & $75.5-76.0$ & -21.4 & $4400 \pm 50$ & 4981 & 5039-4875 & $5276-4854$ \\
\hline SWAN-1016 & $78.5-79.0$ & -20.5 & $3900 \pm 60$ & 4328 & $4417-4248$ & $4514-4152$ \\
\hline SWAN-1017 & $80.5-81.0$ & -21.2 & $4210 \pm 70$ & 4726 & $4849-4628$ & $4875-4526$ \\
\hline SWAN-1018 & $91.5-92.0$ & -20.6 & $4700 \pm 60$ & 5433 & $5575-5324$ & $5583-5316$ \\
\hline SWAN-1019 & $106.5-107.0$ & -19.0 & $5140 \pm 80$ & 5885 & $5988-5751$ & $6175-5662$ \\
\hline SWAN-1020 & $181.5-182.0$ & -17.8 & $8390 \pm 80$ & 9398 & 9489-9306 & $9534-9141$ \\
\hline SWAN-1021 & 189.5-190.0 & -17.3 & $9000 \pm 70$ & 10156 & 10242-9948 & 10266-9905 \\
\hline
\end{tabular}




\section{SHD ages}

Mean R-values for individual moraine sections together with mean ages and $2 \sigma$ uncertainties for both study locations based on the two calibration curves are shown in Table 2. For the Sognefjell moraines, R-values produced older mean calibrated ages using the S \& E Smørstabbtindan (9080 \pm 490 to 10,030 $\pm 500 \mathrm{yr}$ ) than the W Smørstabbtindan ( $7885 \pm 415$ to $8800 \pm 415 \mathrm{yr}$ ) calibration curve (Table 2). The two inner moraine sections produced ages lying between those of the outer moraine sections rather than being younger than them.

The Styggedalsbreen moraine R-values yielded mean ages using either calibration curve mostly in chronological order but they are consistently younger than their Sognefjell counterparts by $\sim 300$ to 1800 years, giving age ranges of $7515 \pm 470$ to $8780 \pm 465$ yr using the S \& E Smørstabbtindan calibration curve and $6380 \pm 410$ to $7595 \pm 390$ yr using the W Smørstabbtindan curve.

Table 2. Schmidt-hammer R-values, associated statistics and Schmidt-hammer exposure ages (SHD) ( $\pm 2 \sigma)$ for earlyHolocene Sognefjell and Styggedalsbreen moraines on outer (O1 and O2) and inner (I1 and 12) moraine sections. In the last two columns, predicted ages are given using two different calibration curves given by Matthews \& Owen (2010).

\begin{tabular}{|c|c|c|c|c|c|}
\hline \multirow{2}{*}{$\begin{array}{l}\text { Moraine ridge } \\
\text { and section no. }\end{array}$} & \multirow[t]{2}{*}{$\mathrm{n}$} & \multirow{2}{*}{$\begin{array}{c}\text { Mean } \\
\text { R-value }\end{array}$} & \multirow[t]{2}{*}{$2 \sigma$} & \multicolumn{2}{|c|}{ SHD $\pm 2 \sigma$ using the following calibration curve } \\
\hline & & & & S \& E Smørstabbtindan & W Smørstabbtindan \\
\hline \multicolumn{6}{|l|}{ Sognefjell } \\
\hline 01 & 150 & 39.03 & 1.04 & $10,030 \pm 500$ & $8,800 \pm 415$ \\
\hline $\mathrm{O} 2$ & 150 & 41.64 & 1.01 & $9,080 \pm 490$ & $7,885 \pm 415$ \\
\hline 11 & 150 & 39.63 & 1.06 & $9,920 \pm 500$ & $8,590 \pm 420$ \\
\hline 12 & 150 & 41.02 & 1.14 & $9,310 \pm 515$ & $8,105 \pm 445$ \\
\hline \multicolumn{6}{|l|}{$\begin{array}{l}\text { Styggedals- } \\
\text { breen }\end{array}$} \\
\hline $\mathrm{O} 1$ & 150 & 42.87 & 0.93 & $8,635 \pm 450$ & $7,455 \pm 380$ \\
\hline $\mathrm{O} 2$ & 150 & 42.47 & 0.98 & $8,780 \pm 465$ & $7,595 \pm 390$ \\
\hline 11 & 150 & 43.33 & 0.84 & $8,470 \pm 425$ & $7,295 \pm 350$ \\
\hline 12 & 150 & 45.95 & 1.05 & $7,515 \pm 470$ & $6,380 \pm 410$ \\
\hline
\end{tabular}




\section{${ }^{10}$ Be surface exposure ages}

The ${ }^{10} \mathrm{Be}$ surface exposure ages and $1 \sigma$ age uncertainties for the western Norway calibration dataset are given in Table 3. These ages are shown together with $1 \sigma$ and $2 \sigma$ age uncertainties in Fig. 6 . Including their age uncertainties $( \pm 1 \sigma)$, the three samples from the Sognefjell inner, intermediate and outer moraine ridges yielded ages of $7.47 \pm 0.52 \mathrm{ka}$ to $9.52 \pm 0.59 \mathrm{ka}$ and the two younger dates (RS-6 and RS-20) narrow the age range including $1 \sigma$ uncertainties to $6.95 \mathrm{ka}$ to $8.54 \mathrm{ka}$. The third sample (RS-7) gives the oldest age of $9.52 \pm 0.59 \mathrm{ka}$, though it is out of stratigraphic order (Table 3 ).

For the Styggedalsbreen moraines, two (RS-11 and RS-30) of the three samples, respectively, gave similar ages and uncertainties of $8.68 \pm 0.61 \mathrm{ka}$ and $8.61 \pm 0.53 \mathrm{ka}$. The third sample, RS- 1 , gave an age of 13.5 $\pm 0.82 \mathrm{ka}$, and is not only the oldest from either location, but also considerably out of stratigraphic order.

Table 3. ${ }^{10}$ Be sample locations, analytical data and surface exposure ages.

\begin{tabular}{llccccc}
\hline Sample ID & \multicolumn{1}{c}{ Location } & $\begin{array}{c}\text { Latitude } \\
\left({ }^{\circ} \mathrm{N}\right)\end{array}$ & $\begin{array}{c}\text { Longitude } \\
\left({ }^{\circ} \mathrm{E}\right)\end{array}$ & $\begin{array}{c}\text { Altitude } \\
(\mathrm{m})\end{array}$ & $\begin{array}{c}\text { Thickness } \\
(\mathrm{cm})\end{array}$ & Shielding $^{\mathrm{a}}$ \\
\hline RS-11 & $\begin{array}{l}\text { Styggedalsbreen (fossil } \\
\text { sorted circles) }\end{array}$ & 61.4960 & 7.8756 & 1268 & 2 & 0.9925 \\
RS-1 & Styggedalsbreen (inner) & 61.4970 & 7.8711 & 1261 & 3 & 0.9931 \\
RS-30 & Styggedalsbreen (outer) & 61.4982 & 7.8788 & 1278 & 2 & 0.9929 \\
RS-7 & Sognefjell (inner) & 61.5233 & 7.8436 & 1280 & 2 & 0.9903 \\
RS-6 & Sognefjell (outer) & 61.5214 & 7.8510 & 1407 & 2 & 0.9961 \\
RS-20 & Sognefjell (intermediate) & 61.5256 & 7.8527 & 1387 & 2 & 0.9951 \\
\hline
\end{tabular}

\begin{tabular}{|c|c|c|c|c|c|c|c|}
\hline \multirow[b]{2}{*}{ Sample ID } & \multirow[b]{2}{*}{ Quartz (g) } & \multirow[b]{2}{*}{${ }^{9}$ Be spike ( $\mu g$ ) } & \multirow[b]{2}{*}{$\begin{array}{c}{ }^{10} \mathrm{Be} /{ }^{9} \mathrm{Be}^{\mathrm{b}} \\
\left(\times 10^{-15}\right)\end{array}$} & \multirow[b]{2}{*}{$\begin{array}{l}\text { Process blank }{ }^{c} \\
{ }^{10} \text { Be atoms }\left(\times 10^{3}\right)\end{array}$} & \multirow[b]{2}{*}{$\begin{array}{c}\left.{ }^{[10} \mathrm{Be}\right]^{\mathrm{d}} \\
\left(\times 10^{4} \text { at g }{ }^{-1} \mathrm{SiO}_{2}\right)\end{array}$} & \multicolumn{2}{|c|}{${ }^{10} \mathrm{Be}$ exposure ages $(\mathrm{ka})^{\mathrm{e}}$} \\
\hline & & & & & & $\begin{array}{l}\text { CRONUSv3 } \\
\text { W. Norway }\end{array}$ & $\begin{array}{c}\text { CRONUSv3 } \\
\text { Global }\end{array}$ \\
\hline RS-11 & 9.016 & 230.6 & $219.57 \pm 4.72$ & $58.8 \pm 8.5$ & $12.602 \pm 0.572$ & $8.68 \pm 0.61$ & $8.87 \pm 0.66$ \\
\hline RS-1 & 17.324 & 233.9 & $19.19 \pm 0.575$ & $58.8 \pm 8.5$ & $19.190 \pm 0.575$ & $13.5 \pm 0.82$ & $13.8 \pm 0.91$ \\
\hline RS-30 & 35.727 & 198.7 & $340.94 \pm 10.57$ & $16.6 \pm 5.8$ & $12.626 \pm 0.393$ & $8.61 \pm 0.53$ & $8.81 \pm 0.59$ \\
\hline RS-7 & 20.239 & 219.4 & $196.97 \pm 4.69$ & $70.1 \pm 10.1$ & $13.923 \pm 0.446$ & $9.52 \pm 0.59$ & $9.73 \pm 0.66$ \\
\hline RS-6 & 12.183 & 224.4 & $118.30 \pm 3.46$ & $176.4 \pm 31.6$ & $13.113 \pm 0.577$ & $7.99 \pm 0.55$ & $8.16 \pm 0.6$ \\
\hline RS-20 & 49.841 & 198.6 & $452.26 \pm 20.26$ & $16.6 \pm 5.8$ & $12.006 \pm 0.539$ & $7.47 \pm 0.52$ & $7.62 \pm 0.57$ \\
\hline
\end{tabular}

${ }^{a}$ Sample thickness correction using a rock density of $2.7 \mathrm{~g} \mathrm{~cm}^{-3}$ and $\Lambda=160 \mathrm{~g} \mathrm{~cm}^{-2}$. Horizon shielding calculated using $m=3.3$.

${ }^{b}$ Final $A M S^{10} B e /{ }^{9}$ Be ratio from weighted mean of repeat measurements.

${ }^{C}$ All AMS ratios were corrected for full chemistry procedural blank and calibrated against NIST-4325 AMS ${ }^{10}$ Be/ ${ }^{\circ}$ Be standard reference material with a nominal value of $27,900 \times 10-15$.

${ }^{110} \mathrm{Be}$ concentration derived from final mean ${ }^{10} \mathrm{Be} /{ }^{9} \mathrm{Be}$ ratio. Uncertainty based on final $\mathrm{AMS}{ }^{10} \mathrm{Be} /{ }^{\mathrm{B}} \mathrm{Be}$ error and $2 \%$ error in ${ }^{9} \mathrm{Be}$ spike value.

eSurface exposure ages are calculated using CRONUSv3: version 3 of "The online exposure age calculators formerly known as the CRONUS-Earth online exposure age calculator" (http://hess.ess.washington.edu/math/; https://cosmognosis.wordpress.com/2016/08/01/let-a-hundred-flowers-bloom/; Balco et al. 2008). We used the western Norway production rate of Goehring et al. (2012) and the global CRONUS-Earth "Primary" Be-10 calibration data set of Borchers et al. (2016) accessible via the ICE-D database (http://calibration.ice-d.org/) and the calculator implementations of the LSDn (Lifton et al. 2014) scaling method. Uncertainties ( $\pm 1 \sigma)$ incorporate analytical uncertainties in ${ }^{10} \mathrm{Be}$ measurements and uncertainties in the calibration and scaling methods. Calculated exposure ages assume a post-exposure erosion rate $(\varepsilon)$ of $0 \mathrm{~mm} \mathrm{ka}^{-1}$. 


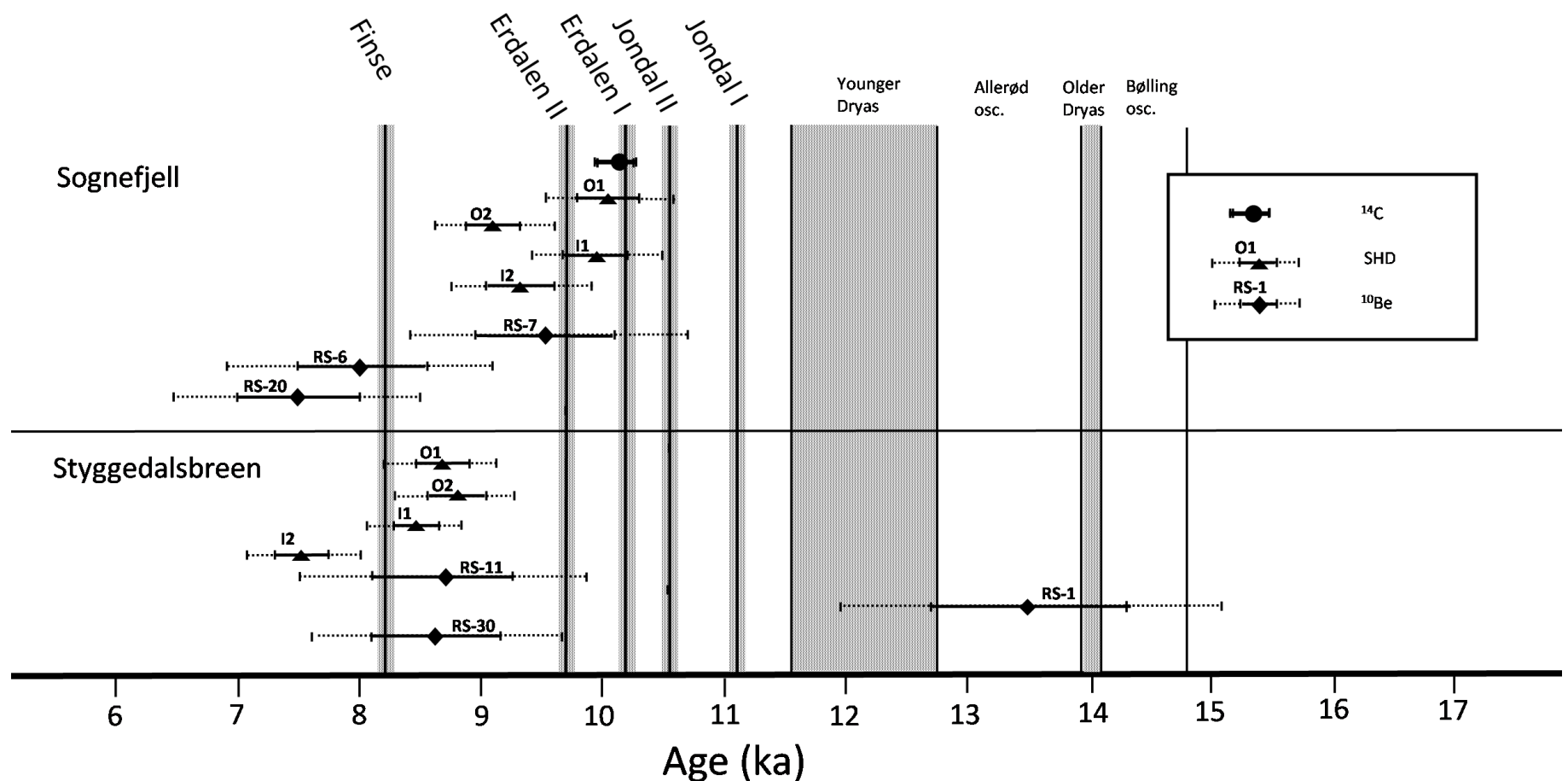

Figure 6. Summary of ages and dating uncertainties. The median calibrated radiocarbon age ( $\pm 1 \sigma$ and $\pm 2 \sigma$ ), and mean SHD and ${ }^{10} B e$ surface exposure ages $( \pm 1 \sigma$ and $\pm 2 \sigma)$ are shown with the sample identifications. Dates for early-Holocene glacier expansion episodes are shown together with shaded columns indicating \pm 100 years. Timing of Late Glacial events follows Mangerud et al. (2016, 2017). See Tables 1-3 for further details.

\section{Discussion}

A graph summarising all the dating results (median basal radiocarbon date and mean SHD and ${ }^{10} \mathrm{Be}$ surface exposure ages with $1 \sigma$ and $2 \sigma$ uncertainties) superimposed on selected early-Holocene and Late Glacial events is shown in Fig. 6.

\section{Interpretation of the radiocarbon evidence}

The earliest calibrated date (10,266-9905 cal BP) from Rydalen 2 provides a minimum age estimate for retreat of the Sognefjell ice cap, which is strongly supported by lake coring evidence from Gjuvvatnet referred to earlier (Karlén \& Matthews, 1992; Nesje, 2009). Further support is provided locally by a radiocarbon date suggesting deglaciation by $\sim 9500$ cal BP from lake sediment in the more proximal Nedste Hervavatnet (Hormes et al., 2009), by an inferred basal date from peat in upper Breidsæterdalen (Shakesby et al., 1990), and by evidence of early-Holocene general glacial retreat reported from elsewhere in southern Norway (e.g., Lie et al., 2004; Nesje, 2009; Aa \& Sønstegaard, 2019). Thus, from the radiocarbon evidence alone, an Erdalen Event glacier expansion episode producing the moraines is strongly supported: although earlier formation is not ruled out, later formation (e.g., during the Finse Event) is.

Radiocarbon dates from the Rydalen mire suggest the stream bank was regularly flooded and eroded for much of the early- and mid-Holocene. Erosion would account for an apparent absence of moss growth and/or peat accumulation between $\sim 9200$ and $\sim 6200$ cal BP in Rydalen 2 and as late as $\sim 4900$ cal BP in Rydalen 1. Between the first and last date, during the Holocene Thermal Maximum (HTM), the Sognefjell ice cap and the Steindalsnosi glacier probably melted completely (cf., Nesje \& Kvamme, 1991; Matthews \& Karlén, 1992; Matthews \& Dresser, 2008; Nesje et al., 2008; Jansen et al., 2008; Seppä et al., 2009), ruling out these ice masses as possible sources of meltwater-transported minerogenic sediment. 
Alternating moss and silt in Rydalen 2 from $\sim 6200$ cal BP may reflect a stream-bank site sufficiently raised by earlier deposition to be sensitive to post-HTM Neoglacial glacial advances and retreats documented in Gjuvvatnet (Karlén \& Matthews, 1992; Nesje, 2009). This sensitivity is absent in Rydalen 1, where there is only a single, relatively thick peat layer yielding bracketing dates out of stratigraphic order in the range $\sim 5300-4600 \mathrm{cal}$ BP, possibly representing a particularly important phase of Neoglacial glacial retreat represented by the numerous, thinner moss layers in Rydalen 2 dated to approximately the same time.

After 3000 cal BP, the stream bank apparently became comparatively stable in view of the uninterrupted, relatively thick, upper peat layer in Rydalen 2, which possibly reflects channel floor lowering by stream downcutting. Otherwise, it is difficult to explain the absence of a silt layer representing the LIA glacier advance in either pit.

\section{Interpretation of the SHD evidence}

For the Sognefjell moraines, the Finse Event age suggested by the W Smørstabbtindan calibration curve is questionable as the geology of the latter is gabbroic with a composition varying from monzonite to quartz monzonite together with 'relict igneous characteristics' (www.geo.ngu.no/kart/ berggrunn). This differs from the Gjuvvatnet location, where much of the bedrock over which ice forming the moraines moved is pyroxene granulite with compositional variations better matching the $S$ \& Smørstabbtindan calibration curve bedrock geology. The moraines overlie a granitic gneiss band, but the short potential glacial transport distance across it means that few granitic gneiss boulders would have reached the moraines. One of the four moraine sites sampled (O2) lies between the Finse and Erdalen events with no overlap of dating uncertainties with either. The $2 \sigma$ dating uncertainties for site 01 overlap the Jondal II (10.5 ka) and Erdalen events. The predicted age and dating uncertainties for the remaining sites I1 and 12, however, overlap only with one or both Erdalen Event phases, so that overall the SHD results favour formation in this episode.

The SHD results for Styggedalsbreen indicate younger ages. The $2 \sigma$ dating uncertainties for two of the results (O1 and I1) overlap with the Finse Event but not the Erdalen Event, a third sample (O2) lies between these two events with no overlap of the dating uncertainties with either event, and the fourth sample suggests only a post-Finse Event age (Fig. 6). There are, however, no additional distal moraines which could represent more extensive Erdalen or Jondal events, as might be expected if the sampled moraines are of Finse Event age, and bedrock geology around Styggedalsbreen differs from that around Gjuvvatnet and the W and S \& E Smørstabbtindan calibration locations, which could explain the young dates. It comprises mostly pyroxene granulite with 'primary hornblende' and with amphibolite altered to pyroxene granulite on the glacier foreland (www.geo.ngu.no/kart/berggrunn). Similarly, McCarroll (1991) noted geological anomalies for boulders on this foreland, which he used to explain unusually low R-values. Otherwise, his overall mean R-value (44.6) for the early-Holocene moraines is similar to ours (43.7) with similarly relatively large inter-site variabilities. As pointed out earlier, the possibility of a Finse Event moraine at Austanbotnbreen (Shakesby et al., 2008) has since been rejected (Matthews \& Winkler, 2011) and another at Grovabreen (Aa \& Sønstegaard, 2019) remains speculative. Furthermore, although Kerschner et al. (2006) and Kerschner \& Ivy Ochs (2008) reported ${ }^{10}$ Be surface exposure ages from the Austrian Alps suggesting 8.2 ka moraines, thus lending some credence to possible Finse Event moraines in southern Norway, newer cosmogenic data indicate an older date (Moran et al., 2016).

\section{Interpretation of the ${ }^{10} \mathrm{Be}$ surface exposure ages}

At both study locations the ${ }^{10} \mathrm{Be}$ surface exposure ages exhibit large age differences and dates out of stratigraphic order. Certain conclusions can, however, be drawn. The possibility of a Late Glacial age for 
RS-1 at Styggedalsbreen (Fig. 6) can be rejected given: (1) most importantly, the continued extensive ice cover at the time (e.g., Hughes et al., 2016; Stroeven et al., 2016; Patton et al., 2017). The most plausible reasons for the erroneously old age are inherited cosmogenic nuclides caused by: (1) boulder removal from a previously exposed, well weathered, headwall surface with little subsequent erosion (cf., Winkler \& Matthews, 2010a); or (2) boulder removal from the headwall and exposure on the foreland after initial glacial deposition followed by incorporation into the moraine. The latter scenario is supported by modern Styggedalsbreen moraines formed by incremental stacking of proglacial slabs through annual freezing-on and subsequent melt-out (Matthews et al., 1995; Winkler \& Matthews, 2010b; Hiemstra et al., 2015). The $1 \sigma$ uncertainties for the ${ }^{10} \mathrm{Be}$ surface exposure ages for the other two Styggedalsbreen samples (RS-11 and RS-30) overlap with the Finse Event: the $2 \sigma$ uncertainties also overlap or just fall short of the late phase of the Erdalen Event (Fig. 6).

For the Sognefjell moraines, the ${ }^{10} \mathrm{Be}$ surface exposure ages for RS- 6 and RS20 from the outer moraine ridges indicate a Finse Event age (Table 3; Fig. 6). In contrast, the ${ }^{10} \mathrm{Be}$ surface exposure age of RS-7 supports formation during the Erdalen Event, though the upper $2 \sigma$ uncertainty also overlaps with the Jondal II Event (Fig. 6). RS-7, however, is out of sequence, located on the stratigraphically younger inner moraine compared to the other two samples from more distal moraine ridges. This could indicate that the higher cosmogenic nuclide concentration in RS-7, as suggested for RS-1, is a result of cosmogenic nuclide inheritance due to derivation of the boulder from a previously exposed headwall. Unlike RS-1, however, the date for RS-7 cannot be dismissed out of hand on the basis that it is clearly erroneous. An alternative explanation is that, despite appearances, in the past, RS- 6 and RS-20 boulders were subject to disturbance and consequent age under-estimation as a result of factors such as toppling or shielding by soil, or the snow layer was much deeper and/or denser than we suppose.

\section{Assessment of the three dating techniques and likely dates of moraine formation}

The strengths and an important weakness of SHD have been well illustrated. The main strengths are cheapness, relatively fast data acquisition, applicability to the Holocene and, especially important, small dating uncertainties with large sample sizes (Winkler, 2009; Matthews \& Owen, 2010; Winkler \& Matthews, 2010a; Matthews \& Winkler, 2011; Wilson et al., 2019). Whilst most non-age-related factors affecting R-values are thought to have been successfully controlled, weathering differences amongst the broadly similarly-classified metamorphic rocks (see Matthews et al., 2016) are thought to have adversely affected the Styggedalsbreen predicted ages.

Both ${ }^{10} \mathrm{Be}$ surface exposure datasets are small and display large age differences in addition to relatively large uncertainties. With no consensus as yet on the best way to solve this problem of age differences, adopted strategies range from: (1) deriving an average date for a moraine (e.g., Saha et al., 2018); to (2) statistical elimination of outliers and calculating a (weighted) average date (e.g., Çiner et al., 2017; Styllas et al., 2018); or (3) selecting only the oldest date (e.g., Heyman et al., 2011; Wüthrich et al., 2018; D’Arcy et al., 2019; Zebre et al., 2019). Although each approach has merit, errors can occur inadvertently through choosing the wrong strategy or through subjective bias. Averaging the three Styggedalsbreen ages would produce a not implausible date $(10.3 \pm 2.8 \mathrm{ka})$ positioned between the early Erdalen and late Jondal events. These averages would, however, include the clearly anomalous RS-1 age (13.8 $\pm 1.16 \mathrm{ka})$. There are too few data to apply the second option and the third is unjustified, again because of a clearly incorrect oldest age. Ages for the Sognefjell moraine boulders are more clustered and the average ( 8.3 $\pm 1.1 \mathrm{ka}$ ) again would be plausible, positioned between the Finse and late Erdalen events, though closer to the former. Too few data again rule out the second strategy, and while the oldest age (RS-7; 9.52 $\pm 0.59 \mathrm{ka}$ ) is compatible with the Erdalen Event, it is stratigraphically out of order. 
Our data also demonstrate the problems with attempting to avoid unwanted environmental influence on the ${ }^{10}$ Be surface exposure ages. Choosing large boulders embedded in stable moraine crests is generally considered effective for avoiding age under-estimation caused by toppling, and shielding by soil, vegetation and snow, and many hold that erosion by warm-based mid-latitude glaciers will remove any inherited nuclides (Heyman et al., 2011; Wüthrich et al., 2018). Jansen et al. (2019), however, found that more than a quarter of sampled ice-sheet-deposited boulders showed significant ${ }^{10} \mathrm{Be}$ inheritance, leading to age over-estimation. In the case of RS-1, its size and stable position seem to have avoided problems of age under-estimation, but instead there was clearly age over-estimation through cosmogenic nuclide inheritance.

The similar basal radiocarbon dates from Rydalen 2 and lake-floor sediment in the upstream Gjuvvatnet suggest dating reliability, although the results are limited to providing a minimum estimate of moraine age. Slow soil development with long organic matter residence time and location in southern Norway above the treeline, however, mean that the paucity up to now of suitable material for radiocarbon dating in or under moraines is unlikely to change.

The Sognefjell moraines are considered to date from the Erdalen Event on the basis that the basal stream-bank and adjacent lake radiocarbon dates are of this age as are three out of four of the SHD dates. This date is also supported by the ${ }^{10} \mathrm{Be}$ surface exposure age for RS-7 (Fig. 6). The Rydalen 2 basal radiocarbon date confirms a substantial body of evidence locally and elsewhere in southern Norway indicating rapid ice wastage shortly after the Erdalen Event. This evidence effectively eliminates a Finse Event date for these moraines, but theoretically all or some of them could date from earlier times (i.e., one or both Jondal Events). Moraines of Jondal Event age in southern Norway, however, have so far only been tentatively identified. Furthermore, for the moraines to date from Erdalen and one or both Jondal events would require ice retreat followed by an Erdalen Event advance extremely close to existing ridges but only rarely overriding them. Intermittent readvances or stillstands during the same (i.e., Erdalen Event) expansion episode featuring similar climatic controls seems a far more likely scenario.

For Styggedalsbreen, the SHD predicted dates and two ${ }^{10} \mathrm{Be}$ surface exposure ages favour more the Finse than the Erdalen Event, but the latter is preferred. Lithological differences between calibration site and the sampled moraines are thought to have resulted in underestimated SHD predicted dates. Furthermore, there is only speculative support for moraines of possible Finse Event age not only locally at Austanbotnbreen, but also elsewhere in southern Norway and in the rest of Europe. The greater distance (typically up to $\sim 1 \mathrm{~km}$ ) between the LIA limit and moraines of Erdalen Event age at the Erdalen type site and other Jostedalsbreen outlet glaciers compared with Styggedalsbreen is entirely consistent with this interpretation, as the former ice mass is much larger with consequently an expected more pronounced glacier response.

Additional support for an Erdalen Event age for the Styggedalsbreen moraines is provided by equilibrium-line altitude (ELA) depression calculations (Table 4). Of the different methods available, accumulation area ratio (AAR) with a ratio of $0.6 \pm 0.05$ was chosen as it has been widely applied to characterise steady-state conditions of valley or cirque glaciers in Norway (Nesje, 1992, 2013). Results using the maximum elevation of lateral moraines (MELM) and toe-to-headwall ratio (THAR) methods proved too inaccurate for Styggedalsbreen because of poor preservation or lack of development of the upper parts of the lateral moraines and little or no difference in the altitude of the glacier snout and thus in the ELAs for the different reconstructed glacier extents. Deciding where to draw contours on a reconstructed glacier is potentially the main source of inaccuracy with the AAR method, although errors are thought to be randomly distributed (Nesje, 1992). For Styggedalsbreen, however, there is the unusual complication of needing to estimate the contribution of ice joining it via the Styggedalen col when the early-Holocene moraines were formed (Vorren, 1973). Estimations of this contribution were guided by the inner and outer lateral 
Table 4. Equilibrium-line altitude (ELA) calculated using the accumulation area ratio (AAR) method applied to Styggedalsbreen at the present day and for the reconstructed Little Ice Age and early-Holocene palaeoglaciers. Lowering of AAR relative to the present day is shown for the palaeoglaciers. (Altitudes for the early-Holocene minimum and maximum glacier extents are adjusted for an isostatic uplift of $90 \mathrm{~m}$.)

\begin{tabular}{lcccc}
\hline & Present day & $\begin{array}{c}\text { Little Ice Age } \\
\text { maximum }\end{array}$ & $\begin{array}{c}\text { Early Holocene } \\
(\text { minimum })^{1}\end{array}$ & $\begin{array}{c}\text { Early Holocene } \\
(\text { maximum })^{2}\end{array}$ \\
\hline AAR $(m \text { a.s.I. })^{3}$ & $1560 \pm 30$ & $1500 \pm 30$ & $1350 \pm 20$ & $1320 \pm 15$ \\
$\Delta$ AAR $(m)$ & N/A & -60 & -210 & -240 \\
\hline
\end{tabular}

${ }^{1}$ Glacier extent is taken as the inner moraine at Styggedalsbreen snout and an estimated contribution from Styggedalen glacier ice based on the lowest lateral moraine.

${ }^{2}$ Glacier extent is taken as the outer moraine at Styggedalsbreen snout and an estimated contribution from Styggedalen glacier ice based on the highest lateral moraine.

${ }^{3}$ The ratio used is $0.6 \pm 0.05$

moraine remnants on the south-facing valley side in Styggedalen (Fig. 3). Despite this complication, the results in Table 4 are regarded as reasonable approximations of the ELAs of the present-day and past glacier extents. This view is supported by the similarity of the ELA for Styggedalsbreen during the LIA maximum to those calculated for glaciers elsewhere in the region. For the LIA maximum, Rasmussen et al. (2010) calculated a regionally averaged altitudinal lowering of the ELA of $68 \pm 44 \mathrm{~m}$ for 133 Jotunheimen glaciers and, for 20 Jostedalsbreen outlet glaciers, Torsnes et al. (1993) reported an average of $75 \pm 30 \mathrm{~m}$. Similarly, there is support from the region for the early-Holocene Styggedalsbreen moraines being of an Erdalen Event age on the basis of similar ELAs. Dahl et al. (2002) reported isostatic-uplift-adjusted ELA lowering of $\sim 230$ and 215 m, respectively, for early and late Erdalen Event moraines at Nigardsbreen, an outlet glacier of Jostedalsbreen. Comparable figures drawn from several sources of 220-285 m for four other Jostedalsbreen outlet glaciers, $205 \mathrm{~m}$ for the northern sector of Hardangerjøkulen and $220 \mathrm{~m}$ for northern Folgefonna were cited by Dahl et al. (2002).

With no convincing moraines of Finse Event age so far identified in Norway, calculating any ELAs is clearly not possible using a method based on palaeoglacier reconstruction. Since, however, in all or virtually all cases, any such moraines were presumably overridden during the LIA readvance, its ELA should lie closer to that of the LIA than to the Erdalen Event, even allowing for the effect of glacio-isostatic uplift. Thus, the large difference between ELAs calculated for the Styggedalsbreen LIA and inner and outer early-Holocene moraines argues against a Finse Event age. On the other hand, ELA calculations adjusted for isostatic uplift for Jondal Events I and II at the type site at northern Folgefonna reported by Bakke et al. (2005b) of $\sim 230 \mathrm{~m}$ and $\sim 220 \mathrm{~m}$ are similar to both the ELA-based glacier extent represented by the Erdalen Event moraines there and the ELAs calculated for the Styggedalsbreen early-Holocene inner and outer moraines (Table 4). Thus, the ELA evidence supports an Erdalen Event rather than Finse Event age for the Styggedalsbreen early-Holocene moraines, though it does not rule out a Jondal Event age.

\section{Implications for early-Holocene glacier variations and climatic fluctuations}

To infer that the moraines at either location date from the Finse Event in particular (though also Jondal events) and not from the Erdalen Event, for which there is already good morphological and dating evidence in southern Norway, would require an overriding balance of supporting evidence. Although some of the new dates, when taken in isolation, point to these other events, there are grounds for doubting their reliability and/or they are matched or outnumbered by Erdalen Event dates. Taking all the dating evidence together as a whole, therefore, we consider that our evidence gives reason to accept an Erdalen Event age at both locations. 
For the investigated multiple moraines all to date from the Erdalen Event requires that both ice masses concerned - ice-cap and large cirque glacier - were similarly sensitive to past fluctuations in ELA. This would suggest an unusual, common glaciological and/or topographic characteristic or set of characteristics. We favour control by a single dominant characteristic, namely the very low-angled marginal terrain at both locations, which would have caused relatively large ice-margin fluctuations in response to small changes in ELA.

Styggedalsbreen would have extended an unusually long distance across a relatively flat glacier foreland when the early-Holocene moraine belt was deposited. The width of this belt narrows to $<200 \mathrm{~m}$ in places compared with more than $800 \mathrm{~m}$ between the present-day glacier and LIA limit (Fig. 3). At least seven, separate, LIA moraines were deposited during 270 years (Matthews, 2005), so that the much narrower early-Holocene moraine belt is fully consistent with formation during the $\sim 500$ years of the Erdalen Event.

Although the Sognefjell former ice-cap thickness is unknown, the outlet glacier occupying the Gjuvvatnet basin would have had a very shallow gradient as reflected in the low-angled slope $\left(\sim 8 \%\right.$ or $\left.\sim 5^{\circ}\right)$ of the outer lateral moraine between its mapped limit north of Steindalsnosi and a point south of sample RS-7 near Gjuvvatnet (Fig. 2). The width of the moraine belt is $<500 \mathrm{~m}$ with an altitudinal range of only $\sim 80 \mathrm{~m}$ (Fig. 2). The ice cap advancing against a valley-side slope would have been conducive to moraine formation and preservation. The low relief of the Sognefjell ice cap would have been similar in some respects to the smaller northern Folgefonna ice cap, where Bakke et al. (2005a) concluded that its limited relief was conducive to rapid responses to minor mass-balance perturbations.

\section{Conclusions}

An Erdalen Event age ( 10.2-9.7 ka) is suggested for the belt of Sognefjell plateau moraines investigated. Although two of the three ${ }^{10} \mathrm{Be}$ surface exposure ages might, at first sight, be viewed as indicating the Finse Event, this contradicts not only the new basal radiocarbon evidence from a proximal stream-bank mire but also published local radiocarbon dates and others in southern Norway, most SHD results, the remaining ${ }^{10} \mathrm{Be}$ surface exposure age and the established, regional, early-Holocene glacial chronology. The narrowness of the moraine belt and rarity of moraine overlap suggest, moreover, readvances or stillstands during a single, multi-centennial-scale, glacier expansion episode.

For the Styggedalsbreen early-Holocene moraines, excluding a clearly erroneous date attributable to cosmogenic nuclide inheritance, the other two ${ }^{10} \mathrm{Be}$ surface exposure ages are positioned between the Finse and late Erdalen events, though nearer the former. The SHD results using the more appropriate S \& E Smørstabbtindan calibration curve also favour the Finse Event, but this is rejected because of subtle but important geological differences between the calibration site and sampled moraine boulders. Support for Erdalen Event formation is provided by the comparability of equilibrium-line altitude (ELA) calculations for Styggedalsbreen to those reported for glaciers of this age elsewhere in the region.

An Erdalen Event age to explain both belts of moraines requires that both ice masses were especially topographically sensitive to small fluctuations in ELA not apparent on other glacier forelands. The Sognefjell ice cap spanned a limited altitudinal range and had a low gradient in the vicinity of the moraines investigated and the terminal zone of Styggedalsbreen extended onto an almost flat foreland. In both cases, therefore, relatively large lateral changes in glacier extent would be expected in response to small changes in ELA. 
demonstrated. The proximal stream-bank mire basal radiocarbon date gave an apparently reliable, though indirect and minimum age estimate for moraine formation. SHD and ${ }^{10} \mathrm{Be}$ surface exposure dating, in comparison, both provided direct, though variable moraine dates. SHD is relatively cheap and able to give rapid results, but is dependent on a close match between rock weathering characteristics at calibration and sampling sites, which proved difficult to achieve in this instance. ${ }^{10} \mathrm{Be}$ surface exposure dating can provide accurate and precise surface exposure ages when an appropriate calibration dataset is used, but is relatively expensive, requires lengthy laboratory analysis and calculated ages obtained from moraine boulders can be affected by a range of post-depositional factors (e.g., boulder instability, and soil, vegetation and snow covers) as well as cosmogenic nuclide inheritance.

The disagreements between and the variations in dates clearly demonstrate the value of a multi-proxy dating approach, which allows offsetting of the different limitations of the techniques. Where possible, for direct dating of early-Holocene boulder moraines, SHD and ${ }^{10} \mathrm{Be}$ surface exposure dating together with any other available applicable technique (e.g., optically-stimulated luminescence dating) should be used. The cheapness and speed of SHD favour its use as both an exploratory and primary technique.

Acknowledgements. Fieldwork was carried out on the Swansea University Jotunheimen Research Expeditions (mainly in 2010-2012 and 2017). RAS is grateful to the Quaternary Research Association for a contribution from the Quaternary Research Fund towards fieldwork costs. We are grateful to Jennifer $L$. Hill, Kay Matthews, Roger S. Matthews, Geraint Owen and Amber Vater for assistance in the field, Maria Miguens-Rodriguez for assistance in ${ }^{10}$ Be sample preparation for accelerator mass spectrometry, and to Geraint Owen, Graham Brumby and Abbey Masonry and Restoration Ltd (Cross Hands, south Wales) for their advice and expertise regarding rock cutting of sample RS-20 ("Hercules"). Anna Ratcliffe drew Fig. 1. Reviewers Atle Nesje and Peter Wilson are thanked for their helpful comments. This paper constitutes Jotunheimen Research Expeditions Contribution No. 217 (See http://jotunheimenresearch. wixsite.com/home).

\section{References}

Aa, A.R. \& Sønstegaard, E. 2019: Early-Holocene glacier fluctuations of northern Grovabreen, western Norway. The Holocene 29, 187-196. https://doi.org/10.1177/0959683618810392.

AhImann, H.W. 1922: Glaciers in Jotunheimen and their physiography. Geografiska Annaler 4, 1-57. https://doi.org/10.1080/20014422.1922.11881048.

AhImann, H.W. 1940: The Styggedal glacier in Jotunheim, Norway. Its regime, its variations in size and their climatological causes, and some general remarks on these. Geografiska Annaler 22, 95-130. https://doi.org/10.2307/519979.

Alley, R.B. \& Ágústsdóttir, A.M. 2005: The 8k event: cause and consequences of a major Holocene abrupt climate change. Quaternary Science Reviews 24, 1123-1149. https://doi.org/10.1016/j.quascirev.2004.12.004.

Alley, R.B., Mayewski, P.A., Sowers, T., Stuiver, M., Taylor, K.C. \& Clark, P.U. 1997: Holocene climatic instability: a prominent, widespread event 8200 yr ago. Geology 25, 483-486.

https://doi.org/10.1130/0091-7613(1997)025<0483:HCIAPW>2.3.CO;2. 
Andersen, J.L. \& Sollid, J.L. 1971: Glacial chronology and glacial geomorphology in the marginal zones of the glaciers Midtdalsbreen and Nigardsbreen, South Norway. Norsk Geografisk Tiddskrift 25, 1-38. https://doi.org/10.1080/00291957108551908.

André, M.F. 1996: Rock weathering rates in Arctic and subarctic environments (Abisko Mts, Swedish Lappland). Zeitschrift für Geomorphologie NF 40, 499-517.

André, M.F. 2002: Rates of postglacial rock weathering on glacially scoured outcrops (Abisko Riksgränsen area $\left.68^{\circ} \mathrm{N}\right)$. Geografiska Annaler 84A, 139-150.

https://doi.org/10.1111/j.0435-3676.2002.00168.x.

Aune, B. 1993: Air temperature normals, normal period 1961-90. Climate Report No. 02/93. Norwegian Meteorological Institute (DNMI), Norway, 63 pp.

Bakke, J., Lie, Ø., Nesje, A., Dahl, S.O. \& Paasche, Ø. 2005a: Utilizing physical sediment variability in glacier-fed lakes for continuous glacier reconstructions during the Holocene, northern Folgefonna, western Norway. The Holocene 15, 161-176. https://doi.org/10.1191/0959683605hl797rp.

Bakke, J., Dahl, S.O. \& Nesje, A. 2005b: Lateglacial and early Holocene palaeoclimatic reconstruction based on glacier fluctuations and equilibrium-line altitudes at northern Folgefonna, Hardanger, western Norway. Journal of Quaternary Science 20, 179-198. https://doi.org/10.1002/jqs.893.

Bakke, J., Trachsel, M., Kvisvik, B.C., Nesje, A. \& Lysa, A. 2013: Numerical analyses of a multi-proxy data set from a distal glacier-fed lake, Sorsendalsvatn, western Norway. Quaternary Science Reviews 73, 182-195. https://doi.org/10.1016/j.quascirev.2013.05.003.

Balco, G. 2011: Contributions and unrealized potential contributions of cosmogenic-nuclide exposure dating to glacier chronology, 1990-2010. Quaternary Science Reviews 30, 3-27. https://doi.org/10.1016/j.quascirev.2010.11.003.

Balco, G. 2019: Isostatic rebound corrections are still on squishy footing. https://cosmognosis.wordpress.com/ (accessed September 18, 2019).

Balco, G., Stone, J.O., Lifton, N.A. \& Dunai, T.J. 2008: A complete and easily accessible means of calculating surface exposure ages or erosion rates from ${ }^{10} \mathrm{Be}$ and ${ }^{26} \mathrm{Al}$ measurements. Quaternary Geochronology 3, 174-195. https://doi.org/10.1016/j.quageo.2007.12.001.

Bickerton, R.W. \& Matthews, J.A. 1993: Little Ice Age variations of outlet glaciers from the Jostedalsbreen ice cap, southern Norway: a regional lichenometric-dating study of ice-marginal moraine sequences and their climatic significance. Journal of Quaternary Science 8, 45-66.

https://doi.org/10.1002/jqs.3390080105.

Borchers, B., Marrero, S, Balco, G., Caffee, M, Goehring, B., Lifton, N., Nishiizumi, K., Phillips, F., Schaefer J. \& Stone, J. 2016: Geological calibration of spallation production rates in the CRONUS-Earth Project. Quaternary Geochronology 31, 188-198. https://doi.org/10.1016/j.quageo.2015.01.009.

Child, D., Elliott, G., Mifsud, C., Smith, A.M. \& Fink, D. 2000: Sample processing for earth science studies at ANTARES. Nuclear Instruments and Methods in Physics Research Section B: Beam Interactions with Materials and Atoms 172, 856-860. https://doi.org/10.1016/S0168-583X(00)00198-1. 
Çiner, A., Sarikaya, M.A. \& Yildirim, C. 2017: Misleading old age or young landform? The dilemma of cosmogenic inheritance in surface exposure dating: Moraines vs. rock glaciers. Quaternary Geochronology 42, 76-88. https://doi.org/10.1016/j.quageo.2017.07.003.

Colman, S.M. 1981: Rock-weathering rates as functions of time. Quaternary Research 15, 250-264. https://doi.org/10.1016/0033-5894(81)90029-6.

Colman, S.M. \& Dethier, D.P. (eds.) 1986: Rates of Chemical Weathering of Rocks and Minerals. Academic Press, Orlando, Florida, USA, 603 pp.

Dahl, S.O. \& Nesje, A. 1992: Paleoclimatic implications based on equilibrium-line altitude depressions of reconstructed Younger Dryas and Holocene cirque glaciers in inner Nordfjord, western Norway. Palaeogeography, Palaeoclimatology, Palaeoecology 94, 87-97. https://doi.org/10.1016/0031-0182(92)90114-K.

Dahl, S.O. \& Nesje, A. 1994: Holocene glacier fluctuations at Hardangerjøkulen, central-southern Norway: a high-resolution composite chronology from lacustrine and terrestrial deposits. The Holocene 4, 269-277. https://doi.org/10.1177/095968369400400306.

Dahl, S.O. \& Nesje, A. 1996: A new approach to calculating Holocene winter precipitation by combining glacier equilibrium-line altitudes and pine-tree limits: a case study from Hardangerjøkulen, central-southern Norway. The Holocene 6, 381-398. https://doi.org/10.1177/095968369600600401.

Dahl, S.O., Nesje, A., Lie, Ø., Fjordheim, K. \& Matthews, J.A. 2002: Timing, equilibrium-line altitudes and climatic implications of two early Holocene glacier advances during the Erdalen Event at Jostedalsbreen, western Norway. The Holocene 12, 17-25. https://doi.org/10.1191/0959683602hl516rp.

Dahl, S.O., Bakke, J., Lie, $\varnothing$. \& Nesje, A. 2003: Reconstruction of former equilibrium-line altitudes based on proglacial sites: an evaluation of approaches and selection of sites. Quaternary Science Reviews 22, 275-287. https://doi.org/10.1016/S0277-3791(02)00135-X.

D'Arcy, M., Schildgen, T.F., Strecker, M.R., Wittjmann, H., Duesing, W., Mey, J., Tofelde, S., Weissmann, P. \& Alonso, R.N. 2019: Timing of past glaciation at the Sierra de Aconquija, northwestern Argentina, and throughout the Central Andes. Quaternary Science Reviews 204, 37-57. https://doi.org/10.1016/j.quascirev.2018.11.022.

Dunai, T.J. 2010: Cosmogenic Nuclides - Principles, Concepts and Applications in the Earth Surface Sciences. Cambridge University Press, Cambridge, MA, $187 \mathrm{pp}$.

https://doi.org/10.1017/СВ09780511804519.

Ellison, C.R.W., Chapman, M.R. \& Hall, I.R. 2006: Surface and deep ocean interactions during the cold climate event 8200 years ago. Science 312, 1929-1932.

https://doi.org/10.1126/science.1127213.

Førland, E.J. 1993: Nedbørnormaler Normalperiode 1961-91. Den norske meteorologiske institutt, Rapport 39-93, 63 pp.

Goehring, B.M., Lohne, Ø.S., Mangerud, J., Svendsen, J.I., Gyllencreutz, R., Schaefer, J., \& Finkel, R. 2012: Late glacial and Holocene ${ }^{10} \mathrm{Be}$ production rates for western Norway. Journal of Quaternary Science 27 , 89-96. https://doi.org/10.1002/jqs.1517. 
Gosse, J.C. \& Phillips, F.M. 2001: Terrestrial in situ cosmogenic nuclides: theory and application. Quaternary Science Reviews 20, 1475-1560.

https://doi.org/10.1016/S0277-3791(00)00171-2.

Griffey, N.J. \& Matthews, J.A. 1978: Major Neoglacial glacier expansion episodes in southern Norway: evidences from moraine ridge stratigraphy with ${ }^{14} \mathrm{C}$ dates on buried palaeosols and moss layers. Geografiska Annaler 60A, 73-90. https://doi.org/10.1080/04353676.1978.11879966.

Heyman, J., Stroeven, A.P., Harbor, J.M. \& Caffee, M.P. 2011: Too young or too old: evaluating cosmogenic exposure dating based on an analysis of compiled boulder exposure ages. Earth and Planetary Science Letters 302, 71-80. https://doi.org/10.1016/j.epsl.2010.11.040.

Hiemstra, J.F., Matthews, J.A., Evans, J.A. \& Owen, G. 2015: Sediment fingerprinting and the mode of formation of singular and composite annual moraine ridges at two glacier margins, Jotunheimen, southern Norway. The Holocene 25, 1772-1785. https://doi.org/10.1177/0959683615591359.

Holzhauser, H., Magny, M. \& Zumbühl, H.J. 2005: Glacier and lake level variations in west-central Europe over the last 3500 years. The Holocene 15, 789-801. https://doi.org/10.1191/0959683605hl853ra.

Hormes, A., Blaauw, M., Dahl, S.O., Nesje, A. \& Possnert, G. 2009: Radiocarbon wiggle-match dating of proglacial lake sediments - Implications for the 8.2 ka event. Quaternary Geochronology 4, $267-277$. https://doi.org/10.1016/j.quageo.2008.12.004.

Hughes, A.L.C., Gyllencreutz, R., Lohne, $\varnothing . S .$, Mangerud, J. \& Svendsen, J.I. 2016: The last Eurasian ice sheets - a chronological database and time-slice reconstruction, DATED-1. Boreas 45, 1-45.

https://doi.org/10.1111/bor.12142.

Jansen, E., Andersson, C., Moros, M., Nisancioglu, K.H., Nyland, B.F. \& Telford, R.J. 2008: The early to mid Holocene thermal optimum in the North Atlantic. In Battarbee, R.W. \& Binney, H.A. (eds.): Natural Climate Variability and Global Warming: a Holocene Perspective, Wiley-Blackwell, Chichester, pp. $128-137$.

Jansen, J., Knudsen, M.F., Andersen, J.L., Heyman, J. \& Egholm, D.L. 2019: Erosion rates in Fennoscandia during the past million years. Quaternary Science Reviews 207, 37-48.

https://doi.org/10.1016/j.quascirev.2019.01.010.

Joerin, U.E., Stocker, T.F. \& Schluchter, C. 2006: Multicentury glacier fluctuations in the Swiss Alps during the Holocene. The Holocene 16, 697-704. https://doi.org/10.1191/0959683606hl964rp.

Karlén, W. \& Matthews, J.A. 1992: Reconstructing Holocene glacier variations from glacial lake sediments: studies from Nordvestlandet and Jostedalsbreen-Jotunheimen, southern Norway. Geografiska Annaler 74A, 327-348. https://doi.org/10.1080/04353676.1992.11880374.

Kerschner, H., Hertl, A., Gross, G., Ivy-Ochs, S. \& Kubik, P.W. 2006: Surface exposure dating of moraines in the Kromer valley (Silvretta Mountains, Austria): evidence for glacial response to the 8.2 ka event in the Eastern Alps? The Holocene 16, 7-15. https://doi.org/10.1196/0959683606hl902rp.

Kerschner, H. \& Ivy-Ochs, S. 2008: Palaeoclimate from glaciers: examples from the Eastern Alps during the Alpine Lateglacial and early Holocene. Global and Planetary Change 60, 59-71.

https://doi.org/10.1016/j.gloplacha.2006.07.034. 
Koestler, A.G. 1989: Hurrungane. Berggrunnsgeologisk kart 1517 IV, scale 1:50,000. Norges geologiske undersøkelse.

Lie, Ø., Dahl, S.O., Nesje, A., Matthews, J.A. \& Sandvold, S. 2004: Holocene fluctuations of a polythermal glacier in high-alpine western Jotunheimen, central southern Norway. Quaternary Science Reviews 23, 1925-1945. https://doi.org/10.1016/j.quascirev.2004.03.012.

Lifton, N., Sato, T. \& Dunai, T.J. 2014: Scaling in situ cosmogenic nuclide production rates using analytical approximations to atmospheric cosmic-ray fluxes. Earth and Planetary Science Letters 386, 149-160. https://doi.org/10.1016/j.epsl.2013.10.052.

Lukas, S. 2007: Early-Holocene glacier fluctuations in Krundalen, south central Norway: palaeoglacier dynamics and palaeoclimate. The Holocene 17, 585-598. https://doi.org/10.1177/0959683607078983.

Lutro, O. \& Tveten, E. 1996: Geologisk Kart over Norge, Berggrunskart Årdal [Geological Map of Norway: Bedrock Map, Årdal Sheet], scale 1:250,000, Norges Geologiske Undersøkelse.

Mangerud, J., Aarseth, I., Hughes, A.L.C., Lohne, Ø., Skår, K., Sønstergaard, E. \& Svendsen, J.I. 2016: A major re-growth of the Scandinavian Ice Sheet in western Norway during Allerød-Younger Dryas. Quaternary Science Reviews 132, 175-205. https://doi.org/10.1016/j.quascirev.2015.11.013.

Mangerud, J., Briner, J.P., Goslar, T. \& Svendsen, J.I. 2017: The Bølling-age Blomvåg Beds, western Norway: implications for the Older Dryas glacial re-advance and the age of deglaciation. Boreas 46, 162-184. https://doi.org/10.1111/bor.12208.

Matthews, J.A. 1985: Radiocarbon dating of surface and buried soils: principles, problems and prospects. In Arnett, R.R. \& Ellis, S. (eds.): Geomorphology and Soils. Allen \& Unwin, London, pp. 269288. https://doi.org/10.4324/9780429320781-14.

Matthews, J.A. 1991: The late Neoglacial ('Little Ice Age') glacier maximum in southern Norway: new ${ }^{14} \mathrm{C}$-dating evidence and climatic implications. The Holocene 1, 219-233.

https://doi.org/10.1177/095968369100100304.

Matthews, J.A. 2005: 'Little Ice Age' glacier variations in Jotunheimen, southern Norway: a study in regionally controlled lichenometric dating of recessional moraines with implications for climate and lichen growth curves. The Holocene 15, 1-19. https://doi.org/10.1191/0959683605hl779rp.

Matthews, J.A. \& Dresser, P.Q. 2008: Holocene glacier variation chronology of the Smørstabbtindan massif, Jotunheimen, Norway, and the recognition of European Neoglacial events. The Holocene 18, 181-201. https://doi.org/10.1177/0959683607085608.

Matthews, J.A. \& Karlén, W. 1992: Asynchronous neoglaciation and Holocene climatic change reconstructed from Norwegian glaciolacustrine sedimentary sequences. Geology 20, 991-994. https://doi.org/10.1130/0091-7613(1992)020<0991:ANAHCC>2.3.CO;2.

Matthews, J.A. \& McEwen, L.J. 2013: High-precision Schmidt-hammer exposure-age dating (SHD) of flood berms, Vetlest $\varnothing$ Isdalen, alpine southern Norway: first application and some methodological issues. Geografiska Annaler 95A, 185-194. https://doi.org/10.1111/geoa.12009. 
Matthews, J.A. \& Owen, G. 2010: Schmidt-hammer exposure-age dating: developing linear age-calibration curves using Holocene bedrock surfaces from the Jotunheimen-Jostedalsbreen regions of southern Norway. Boreas 39, 105-115. https://doi.org/10.1111/j.1502-3885.2009.00107.x.

Matthews, J.A. \& Owen, G. 2011: Holocene chemical weathering, surface lowering and rock weakening rates on glacially eroded bedrock surfaces in an alpine periglacial environment, Jotunheimen, southern Norway. The Holocene 22, 279-290. https://doi.org/10.1002/ppp.697.

Matthews, J.A. \& Shakesby, R.A. 1984: The status of the 'Little Ice Age' in southern Norway: relative-age dating of Neoglacial moraines with Schmidt hammer and lichenometry. Boreas 13, 333-346. https://doi.org/10.1111/j.1502-3885.1984.tb01128.x.

Matthews, J.A. \& Winkler, S. 2011: Schmidt-hammer exposure-age dating (SHD): application to early Holocene moraines and a reappraisal of the reliability of terrestrial cosmogenic-nuclide dating (TCND) at Austanbotnbreen, Jotunheimen, Norway. Boreas 40, 256-270.

https://doi.org/10.1111/j.1502-3885.2010.00178.x.

Matthews, J.A., McCarroll, D. \& Shakesby, R.A. 1995: Contemporary terminal-moraine ridge formation at a temperate glacier: Styggedalsbreen, Jotunheimen, southern Norway. Boreas 24, 129-139. https://doi.org/10.1111/j.1502-3885.1995.tb00633.x.

Matthews, J.A., Dahl, S.O., Nesje, A., Berrisford, M.S. \& Andersson, C. 2000: Holocene glacier variations in central Jotunheimen, southern Norway based on distal glaciolacustrine sediment cores. Quaternary Science Reviews 19, 1625-1647. https://doi.org/10.1016/S0277-3791(00)00008-1.

Matthews, J.A., Berrisford, M.S., Dresser, P.Q., Nesje, A., Dahl, S.O., Bjune, A.E., Bakke, J., Birks, H.J.B., Lie, Ø., Dumayne-Peaty, L. \& Barnett, C. 2005: Holocene glacier history of Bjørnbreen and climatic reconstruction in central Jotunheimen, Norway, based on proximal glaciofluvial stream-bank mires. Quaternary Science Reviews 24, 67-90. https://doi.org/10.1016/j.quascirev.2004.07.003.

Matthews, J.A., Shakesby, R.A., Schnabel, C. \& Freeman, S. 2008: Cosmogenic ${ }^{10}$ Be and ${ }^{26} \mathrm{Al}$ ages of Holocene moraines in southern Norway I: testing the method and confirmation of the date of the Erdalen Event (c. $10 \mathrm{ka}$ ) at its type-site. The Holocene 18, 1155-1164.

https://doi.org/10.1177/0959683608096585.

Matthews, J.A., Winkler, S. \& Wilson, P. 2014: Age and origin of ice-cored moraines in Jotunheimen and Breheimen, southern Norway: insights from Schmidt-hammer exposure-age dating. Geografiska Annaler 96A, 531-548. https://doi.org/10.1111/geoa.12046.

Matthews, J.A., Owen, G., Winkler, S., Vater, A.E., Wilson, P., Mourne, R.W. \& Hill, J.L. 2016: A rock-surface microweathering index from Schmidt hammer R-values and its preliminary application to some common rock types in southern Norway. Catena 143, 35-44. https://doi.org/10.1016/j.catena.2016.03.018.

McCarroll, D. 1987: The Schmidt hammer in geomorphology: five sources of instrument error. British Geomorphological Research Group, Technical Bulletin 36, 16-27.

McCarroll, D. 1991: The Schmidt hammer, weathering and rock surface roughness. Earth Surface Processes and Landforms 16, 477-480. https://doi.org/10.1002/esp.3290160510. 
McCarroll, D. 1994: The Schmidt hammer as a measure of the degree of rock surface weathering and terrain age. In Beck, C. (ed.): Dating in Exposed and Surface Contexts, University of New Mexico Press, Albuquerque, pp. 29-46.

Moran, A.P., Kerschner, H. \& Ivy-Ochs, S. 2016: Redating the moraines in the Kromer Valley (Silvretta Mountains) - New evidence for an early Holocene advance. The Holocene 26, 655-664. https://doi.org/10.1177/0959683615612571.

Mottershead, D.N. \& Collin, R.L. 1976: A study of Flandrian glacier fluctuations in Tunsbergdalen, southern Norway. Norsk Geologisk Tidsskrift 56, 413-436.

Nesje, A. 1984: Kvartærgeologiske undersøkingar i Erdalen, Stryn, Sogne og Fjordane. Unpublished thesis, University of Bergen, $201 \mathrm{pp}$.

Nesje, A. 1992: Topographical effects on the equilibrium-line altitude on glaciers. GeoJournal 27, 383-391. https://doi.org/10.1007/BF00185102.

Nesje, A. 2009: Latest Pleistocene and Holocene glacier fluctuations in Scandinavia. Quaternary Science Reviews 28, 2119-2136. https://doi.org/10.1016/j.quascirev.2008.12.016.

Nesje, A. 2013: Equilibrium-line altitude reconstruction. In Matthews, J.A. (ed.): Encyclopedic dictionary of environmental change, Volume 1, Sage, London, pp. 375-376.

Nesje, A. \& Dahl, S.O. 2001: The Greenland 8200 cal. yr BP event detected in loss-on-ignition profiles in Norwegian lacustrine sediment sequences. Journal of Quaternary Science 16, 155-166. https://doi.org/10.1002/jqs.567.

Nesje, A. \& Kvamme, M. 1991: Holocene glacier and climatic variations in western Norway: evidence for early Holocene glacier demise and multiple Neoglacial events. Geology 19, 610-612. https://doi. org/10.1130/0091-7613(1991)019<0610:HGACVI>2.3.CO;2.

Nesje, A., Kvamme, M., Rye, N. \& Løvlie, R. 1991: Holocene glacial and climatic history of the Jostedalsbreen region, western Norway: evidence from lake sediments and terrestrial deposits. Quaternary Science Reviews 10, 87-114. https://doi.org/10.1016/0277-3791(91)90032-P.

Nesje, A., Dahl, S.O., Andersson, C. \& Matthews, J.A. 2000: The lacustrine sedimentary sequence in Sygneskardvatnet, western Norway: a continuous high-resolution record of the Jostedalsbreen ice cap during the Holocene. Quaternary Science Reviews 19, 1047-1065.

https://doi.org/10.1016/S0277-3791(99)00090-6.

Nesje, A., Matthews, J.A., Dahl, S.O., Berrisford, M.S. \& Andersson, C. 2001: Holocene glacier fluctuations of Flatebreen and winter-precipitation changes in the Jostedalsbreen region, western Norway, based on glaciolacustrine sediment records. The Holocene 11, 267-280. https://doi.org/10.1191/095968301669980885.

Nesje, A., Bjune, A.E., Bakke, J., Dahl, S.O., Lie, Ø. \& Birks, H.J.B. 2006: Holocene palaeoclimate reconstructions at Vanndalsvatnet, western Norway, with particular reference to the $8200 \mathrm{cal}$. yr BP event. The Holocene 16, 717-729. https://doi.org/10.1191/0959683606hl954rp.

Nesje, A., Bakke, J., Dahl, S.O., Lie, Ø. \& Matthews, J.A. 2008: Norwegian glaciers in the past, present and future. Global and Planetary Change 60, 10-27. https://doi.org/10.1016/j.gloplacha.2006.08.004. 
Nicholson, D.T. 2008: Rock control on microweathering of bedrock surfaces in a periglacial environment. Geomorphology 101, 655-665. https://doi.org/10.1016/j.geomorph.2008.03.009.

Nicholson, D.T. 2009: Holocene microweathering rates and processes on ice-eroded bedrock, Røldal area, Hardangervidda, southern Norway. Geological Society of London, Special Publication 320, 29-49. https:// doi.org/10.1144/SP320.3.

Nicolussi, K. \& Patzelt, G. 2000: Discovery of Early Holocene wood and peat on the forefield of the Pasterze Glacier, Eastern Alps, Austria. The Holocene 10, 191-199. https://doi.org/10.1191/095968300666855842.

O'Brien, S.R., Mayewski, P.A., Meeker, L.D., Meese, D.A., Twickler, M.S. \& Whitlow, S.I. 1995. Complexity of Holocene climate as reconstructed from a Greenland ice core. Science 270, 1962-1964. https://doi.org/10.1126/science.270.5244.1962.

Owen, G., Matthews, J.A. \& Albert, P.G. 2007: Rates of Holocene chemical weathering, 'Little Ice Age' glacial erosion and implications for Schmidt-hammer dating at a glacier-foreland boundary, Fåbergstølsbreen, southern Norway. The Holocene 17, 829-834.

https://doi.org/10.1177/0959683607081419.

Patton, H., Hubbard, A., Andreassen, K., Auriac, A., Whitehouse, P.L., Stroeven, A.P., Shackleton, C. Winsborrow, M., Heyman, J. \& Hall, A.M. 2017: Deglaciation of the Eurasian ice sheet complex. Quaternary Science Reviews 169, 148-172. https://doi.org/10.1016/j.quascirev.2017.05.019.

Patzelt, G. 1974: Holocene variations of glaciers in the Alps. International Colloquium, Centre National de la Recherche Scientifique 219, 51-59.

Patzelt, G. \& Bortenschlager, S. 1973: Die postglazialen Gletscher- und Klimaschwankungen in der Venedigergruppe (Hohe Tauern, Ostalpen). Zeitschrift für Geomorphologie N.F., Supplement Band 16, $25-72$.

Paus, A., Haflidason, H., Routh, J., Naafs, B.D.A. \& Thoen, M.A. 2019: Environmental responses to the 9.7 and 8.2 cold events at two ecotonal sites in the Dovre mountains, mid-Norway. Quaternary Science Reviews 205, 45-61. https://doi.org/10.1016/j.quascirev.2018.12.009.

Proceq 2006: Operating Instructions (Betonprüfhammer N/NR-L/LR), Schwerzenbach, Proceq SA, 19 pp.

Rasmussen, L.A., Andreassen, L.M., Baumann, S. \& Conway, H. 2010: 'Little Ice Age' precipitation in Jotunheimen, southern Norway. The Holocene 20, 1039-1045.

https://doi.org/10.1177/0959683610369510.

Reimer, P.J., Bard, E., Bayliss, A., Beck, J.W., Blackwell, P.G., Ramsey, C.B., Buck, C.E., Cheng, H., Edwards, R.L., Friedrich, M., Grootes, P.M., Guilderson, T.P., Haflidason, H., Hajdas, H., Hatté, C., Heaton, T.J., Hoffmann, D.L., Hogg, A.G., Hughen, K.A., Kaiser, K.F., Kromer, B., Manning, S.W., Niu, M., Reimer, R.W., Richards, D.A., Scott, E.M., Southon, J.R., Staff, R.A., Turney, C.S.M. \& van der Pflicht, J. 2013: IntCal13 and Marine13 radiocarbon age calibration curves 0-50,000 years cal BP. Radiocarbon 55(4), 1869-1887. https://doi.org/10.2458/azu_js_rc.55.16947.

Rohling, E.J. \& Pälike H. 2005: Centennial-scale climate cooling with a sudden cold event around 8,200 years ago. Nature 434, 975-979. https://doi.org/10.1038/nature03421. 
Röthlisberger, F. 1986: 10,000 Jahre Gletschergeschichte der Erde: ein Vergleich zwischen Nord- und Südhemisphäre. Sauerländer Aarau, Frankfurt, 416 pp.

Saha, S., Owen, L.A., Orr, E.N. \& Caffee, M.W. 2018: Timing and nature of Holocene glacier advances at the northwestern end of the Himalayan-Tibetan orogen. Quaternary Science Reviews 187, 177-202. https://doi.org/10.1016/j.quascirev.2018.03.009.

Seierstad, J., Nesje, A., Dahl, S.O. \& Simonsen, J. 2002: Holocene glacier fluctuations of Grovabreen and Holocene snow-avalanche activity reconstructed from lake sediments in Grøningst $\varnothing$ lsvatnet, western Norway. The Holocene 12, 211-22. https://doi.org/10.1191/0959683602hl536rp.

Seppä, H., Bjüne, A.E., Telford, R.J., Birks, H.J.B., Birks, H.H. \& Veski, S. 2009: Last nine-thousand years of temperature variability in Northern Europe. Climate Past 5, 523-535. https://doi.org/10.5194/cp-5-523-2009.

Shakesby, R.A., McCarroll, D. \& Caseldine, C.J. 1990: New evidence for Preboreal deglaciation of southcentral Norway. Norsk Geografisk Tidsskrift 44, 121-130. https://doi.org/10.1080/00291959008552250.

Shakesby, R.A., Matthews, J.A. \& Owen, G. 2006: The Schmidt hammer as a relative-age dating tool and its potential for calibrated-age dating in Holocene glaciated environments. Quaternary Science Reviews 25, 2846-2867. https://doi.org/10.1016/j.quascirev.2006.07.011.

Shakesby, R.A., Smith, J.G., Matthews, J.A., Winkler, S., Dresser, P.Q., Nesje, A., Dahl, S.O. \& Bakke, J. 2007: Reconstruction of Holocene glacier history from distal sources: glaciofluvial stream-bank mires and glaciolacustrine sediment core near Sota Sæter, Breheimen, southern Norway. The Holocene 17, 729-745. https://doi.org/10.1177/0959683607080514.

Shakesby, R.A., Matthews, J.A. \& Schnabel, C. 2008: Cosmogenic ${ }^{10} \mathrm{Be}$ and ${ }^{26} \mathrm{Al}$ ages of Holocene moraines in southern Norway II: evidence for individualistic responses of high-altitude glaciers to millennial-scale climatic fluctuations. The Holocene 18, 1165-1177. https://doi.org/10.1177/0959683608096592.

Shakesby, R.A., Matthews, J.A., Karlén, W. \& Los, S. 2011. The Schmidt hammer as a Holocene calibrated-age dating technique: testing the form of the R-value - age relationship and defining predicted errors. The Holocene 21, 615-628. https://doi.org/10.1177/0959683610391322.

Stroeven, A.P., Hattestrand, C., Kleman, J., Heyman, J., Fabel, D., Fredin, O., Goodfellow, B.W., Harbor, J.M., Jansen, J.D., Olsen, L., Caffee, M.W., Fink, D., Lundqvist, J., Rosqvist, G.C., Stromberg, B. \& Jansson, K.N. 2016: Deglaciation of Fennoscandia. Quaternary Science Reviews 147, 91-121. https://doi.org/10.1016/j.quascirev.2015.09.016.

Stuiver, M. \& Reimer, P.J. 2017: CALIB REV 7.0.4. [www program and documentation].

Styllas, M.N., Schimmelpfennig, I., Benedetti, L. \& Ghilardi, M. 2018: Late-glacial and Holocene history of the northeast Mediterranean mountain glaciers - New insights from in-situ produced $\mathrm{Cl}$-36-based cosmic ray exposure dating of paleo-glacier deposits on Mount Olympus. Quaternary Science Reviews 193, 244-265. https://doi.org/10.1016/j.quascirev.2018.06.020.

Tomkins, M.D., Dortch, J.M. \& Hughes, P.D. 2016: Schmidt hammer exposure dating (SHED): establishment and implications for the retreat of the last British Ice Sheet. Quaternary Geochronology 33, 46-60. https://doi.org/10.1016/j.quageo.2016.02.002. 
Tomkins, M.D., Dortch, J.M., Hughes, P.D., Huck, J.J., Kirkbride, M.P. \& Barr, I.D. 2018a: Schmidt hammer exposure-age dating (SHED): calibration procedures, new exposure-age data and an online calculator. Quaternary Geochronology 44, 55-62. https://doi.org/10.1016/j.quageo.2017.12.003.

Tomkins, M.D., Dortch, J.M., Hughes, P.D., Huck, J.J., Stimson, A., Delmas, M., Calvet, N. \& Pallàs, A. 2018b: Schmidt hammer exposure-age dating (SHED): rapid age assessment of glacial landforms in the Pyrenees. Quaternary Research 90, 26-37. https://doi.org/10.1017/qua.2018.12.

Torsnes, I., Rye, N. \& Nesje, A. 1993: Modern and Little Ice Age equilibrium-line altitudes on outlet glaciers from Jostedalsbreen, western Norway: an evaluation of different approaches to their calculation. Arctic and Alpine Research 25, 106-116. https://doi.org/10.2307/1551546.

Vorren, T.O. 1973: Glacial geology of the area between Jostedalsbreen and Jotunheimen, south Norway. Norges geologiske Undersøkelse 291, 1-46.

Wilson, P., Linge, H., Matthews, J.A., Mourne, R.W. \& Olsen, J. 2019: Comparative numerical surface exposure-age (10Be and Schmidt hammer) of an early-Holocene rock avalanche at Alstadfjellet, Valldalen, southern Norway. Geografiska Annaler 101A, 293-309.

https://doi.org/10.1080/04353676.2019.1644815.

Winkler, S. 2009: First attempt to combine terrestrial cosmogenic nuclide $\left({ }^{10} \mathrm{Be}\right)$ and Schmidt hammer relative-age dating, Strauchon Glacier, Southern Alps, New Zealand. Central European Journal of Geosciences 1, 274-290. https://doi.org/10.2478/v10085-009-0026-3.

Winkler, S. \& Matthews, J.A. 2010a: Holocene glacier chronologies: are high-resolution global and inter-hemispherical comparisons possible? The Holocene 20, 1137-1147.

https://doi.org/10.1177/0959683610369511.

Winkler, S. \& Matthews, J.A. 2010b: Observations on terminal moraine-ridge formation during recent advances of southern Norwegian glaciers. Geomorphology 116, 87-106. https://doi.org/10.1016/j.geomorph.2009.10.011.

Winkler, S., Matthews, J.A., Shakesby, R.A. \& Dresser, P.Q. 2003: Glacier variations in Breheimen, southern Norway: dating Little Ice Age sequences at seven low-altitude glaciers. Journal of Quaternary Science 18, 395-413. https://doi.org/10.1002/jqs.756.

Wüthrich, L., Morabito, E.G., Zech, J., Trauerstein, M., Veit, H., Gnägl, C., Merchel, S., Scharf, A., Rugel, G., Christl, M. \& Zech, R. 2018: ${ }^{10} \mathrm{Be}$ exposure dating of the last deglaciation in the Aare Valley, Switzerland. Swiss Journal of Geosciences 111, 295-303. https://doi.org/10.1007/s00015-018-0298-3.

Xu, S., Dougans, A.B. \& Freeman, S. 2010: Improved Be-10 and Al-26 AMS with a 5 MV spectrometer. Nuclear Instruments \& Methods in Physics Research, Section B: Beam Interactions with Materials and Atoms 268, 737-738. https://doi.org/10.1016/j.nimb.2009.10.018.

Zebre, M., Sarikaya, M.A., Stepisnik, U., Yildirim C. \& Çiner, A. 2019. First Cl-36 moraine geochronology of the Dinaric mountain karst: Velez and Crvanj Mountains of Bosnia and Herzegovina. Quaternary Science Reviews 208, 54-75. https://doi.org/10.1016/j.quascirev.2019.02.002. 